\title{
Avifauna of the Pilón Lajas Biosphere Reserve and Communal Lands, Bolivia
}

\author{
A. BENNETT HENNESSEY, SEBASTIAN A. HERZOG, MICHAEL KESSLER \\ and DANIEL ROBISON
}

\begin{abstract}
Summary
Pilón Lajas Biosphere Reserve and Communal Lands (Pilón Lajas) ranges from $300 \mathrm{~m}$ to $1,400 \mathrm{~m}$ altitude in the departments of Beni and La Paz, Bolivia. It is located in the Bolivian and Peruvian lower yungas Endemic Bird Area (054) and within one of the regions of highest conservation priority in the Neotropics. Pilón Lajas includes primary evergreen tropical lowland forest, foothill forest, and lower montane forest. Vegetation heterogeneity forms the basis for the high species richness of the area. A population of approximately 600 Chiman, Moseten and Tacana indigenous people live within the reserve. Little has been published regarding the avifauna of Pilón Lajas. Here we present the results of visual observations and tape recordings of 22 ornithological surveys, recording 502 bird species. Serranía Pilón is the most intensively studied and species-rich mountain range with 332 species, 48 of which have been recorded only in this area within Pilón Lajas. We present 26 new departmental records and evidence of breeding for 42 species. The reserve protects three globally Vulnerable and three globally Near Threatened species, four species of High Conservation Priority and 32 of Medium Conservation Priority. Together with Madidi National Park and the adjacent Bahuaja Sonene National Park in south-eastern Peru, Pilón Lajas forms a unique protected area system of more than 3.5 million ha and plays an important role in the establishment of biological corridors along the eastern Andean slope in Bolivia.
\end{abstract}

\section{Introduction}

Pilón Lajas Biosphere Reserve and Communal Lands (Reserva de la Biósfera Tierra Comunitaria de Orígen Pilón Lajas in Spanish, hereafter referred to as Pilón Lajas) covers c. 400,00o ha on the Andean foothills in north-west Bolivia (Figure 1). It is located in the Bolivian and Peruvian lower yungas Endemic Bird Area (EBA 054) of Stattersfield et al. (1998) and within one of the regions of highest conservation priority in the Neotropics (Stotz et al. 1996). Initially proposed in 1974, Pilón Lajas was recognized as a Biosphere Reserve by UNESCO in 1977 and as a Biosphere Reserve and Indigenous Territory by the Bolivian Government in 1992 (Sherholtz 1997). The area was legally designated but had no physical protection until 1994, when Veterinarians Without Frontiers (VSF) received funding from the European Union to design an operational plan for the reserve. Through an agreement with the Bolivian National Protected Areas Service, VSF has been co-administering Pilón Lajas since 1996.

Pilón Lajas is in an area with a moderate level of historic and current human activity and settlement. A population of approximately 600 Chiman, Moseten 


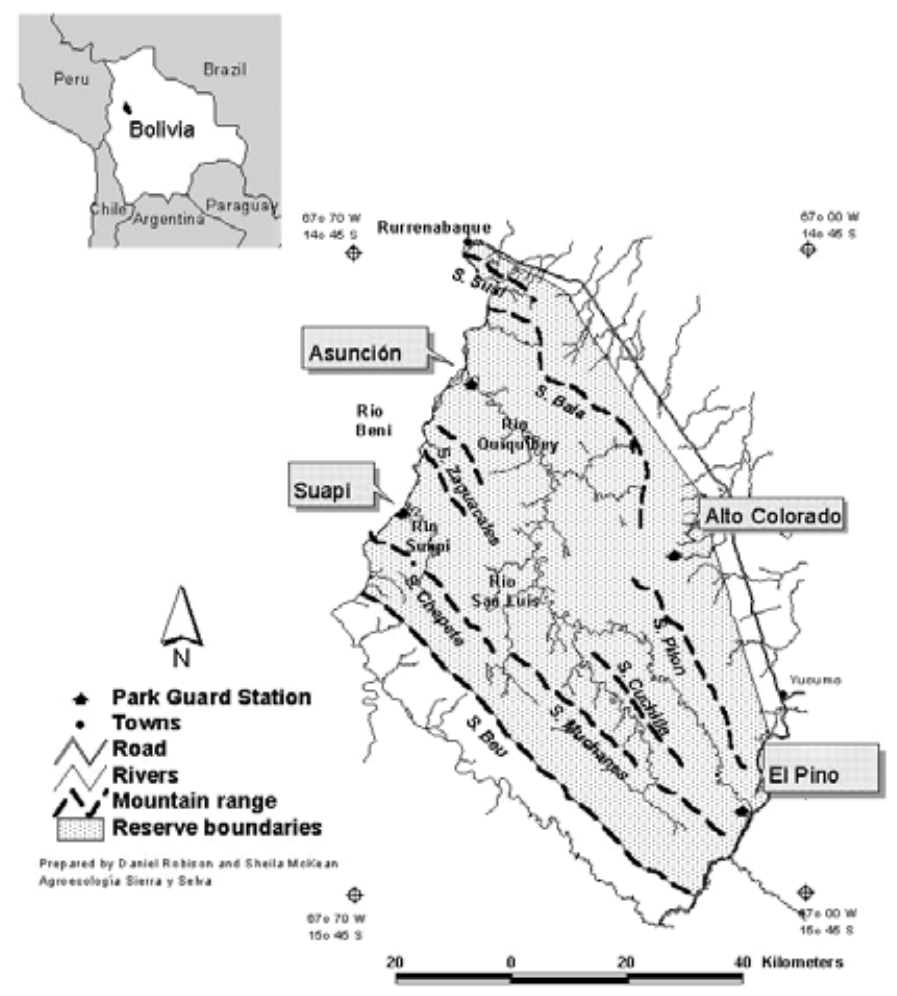

Figure 1. Map showing Pilón Lajas Biosphere Reserve, Bolivia.

and Tacana indigenous people live within the reserve. The Beni River, the western border of Pilón Lajas (Figure 1), was the principal "highway" between the Andes and the rubber/brazil nut forests to the north for a century until a new road was completed in 1989. This new road, forming Pilón Lajas' eastern border and connecting the area to the city of La Paz, was used for a governmentsponsored colonization programme of families from other parts of the country. Many of these colonists believe they have a right to land within Pilón Lajas. Although parts of the reserve are extremely remote, requiring expeditions of several days to be reached, other parts have long been accessible. It is estimated that only $1 \%$ of Pilón Lajas has been deforested for agriculture in the last century, but perhaps $80 \%$ of the lower tropical forest has been heavily hunted during the alligator hide and wildlife skin boom in the 1960s and 1970s. Between 1980 and 1996, the mahogany lumber boom heavily affected the same area, particularly within $10 \mathrm{~km}$ of rivers and large streams. Up until 1996, five lumber companies with dubious legal status and approximately 300 chain sawyers selectively logged and hunted in the reserve.

The Pilón Lajas management plan has subdivided the reserve into specific zones to combine indigenous community rights with conservation initiatives. Since 1996, a core of 20 park guards (many belonging to local indigenous groups) has been hired and trained and four park guard stations have been established in highly sensitive areas along borders to protect the reserve. 
Table 1. Survey areas visited by 22 ornithological expeditions in Pilón Lajas, Bolivia, between 1989 and 1999 .

\begin{tabular}{lll}
\hline Survey area & Elevational range $(\mathrm{m})$ & Number of visits \\
\hline Lowland forest areas & $350-500$ & 5 \\
Serranía Bala & $450-800$ & 2 \\
Serranía Beu & $500-1,400$ & 4 \\
Serranía Cuchilla & $450-1,000$ & 2 \\
Serranía Pilón & $400-1,100$ & 8 \\
Serranía Zaguacales & $400-800$ & 1 \\
\hline
\end{tabular}

The aim of this paper is to bring together unpublished avifaunal information into an extensive document that can be used for informed conservation decision making and land protection priority assessments. This is important for the protection and global attention of Pilón Lajas and the general Andean protected area corridor of Madidi and Bahuaja Sonene National Parks.

\section{Methods}

This paper is based on 22 unpublished ornithological surveys by 15 researchers over 148 days between 1989 and 1999 (Table 1, Appendix 1) in Pilón Lajas. The principal survey methods were non-systematic visual and acoustic observations as well as tape recordings of vocalisations. Limited mist-netting was carried out by the first author (ABH) in Serranía Cuchilla in 1999 and by F. Osorio and others (Colección Boliviana de Fauna, La Paz; Appendix 1). A small number of specimens were collected by F. Osorio and others and deposited at the Colección Boliviana de Fauna.

Altitude ranges and abundance estimates are based on survey results by $\mathrm{ABH}$. $\mathrm{ABH}$ surveyed different points at least $200 \mathrm{~m}$ apart, arriving before sunrise and identifying and sound-recording vocalizations of the dawn chorus. Thereafter, different trails were surveyed, covering $1-3 \mathrm{~km}$, often pausing work between 12 hoo and 15 hoo. ABH observed, sound-recorded and verified identifications with the use of prerecorded tapes or playback, including rebound playback (broadcasting the first response to playback). Each evening $\mathrm{ABH}$ completed a checklist of the day's observations, noting estimated abundances, field time, distance walked and evidence (sight records, heard or tape-recorded). Abundance estimates were classified as; common, recorded (visual observation or auditory) daily in small numbers ( $>5$ ); fairly common, recorded daily in small numbers $(<5)$; uncommon, recorded once in three days; and rare, recorded once during the survey. Tape-recording bird vocalizations is the most effective method for rapidly surveying neotropical forest avifaunas (Parker 1991; see also Haselmayer and Quinn 2000) and is an accurate means of species identification that can be easily referenced. Over 400 recordings by $\mathrm{ABH}$ from Pilón Lajas have been archived at the Cornell Laboratory of Ornithology, Macaulay Library of Natural Sounds (MLNS). Fieldwork covered all months except for January, March and May, and included all habitat types within Pilón Lajas and as much area as possible with the largest gap between sites being $15 \mathrm{~km}$. For the purpose of vegetation classification, we used the elevational belts of Stotz et al. (1996): lower 
tropical forest $(<500 \mathrm{~m})$, hill tropical forest $(500-900 \mathrm{~m}$ ) and upper tropical forest (900-1,600 m). This was modified as necessary by reference to topographical location (level areas, slopes, ridges, etc.), geological substrate and state of vegetation succession. It should be noted that Parker (1989) erroneously gave 1,200 $\mathrm{m}$ as the highest altitude of the road crossing Serranía Pilón south of Yucumo (Figure 1). Rather, as indicated by Parker et al. (1991) and as confirmed by our measurements, the highest point of this road is located at $c .1,000 \mathrm{~m}$.

\section{Study Area}

Pilón Lajas is situated at $14^{\circ} 26^{\prime}$ to $15^{\circ} 28^{\prime} \mathrm{S}$ and $68^{\circ} 42^{\prime}$ to $68^{\circ} \mathrm{O} 2^{\prime} \mathrm{W}$ in Beni and La Paz departments with an altitudinal range from $300 \mathrm{~m}$ to $1,400 \mathrm{~m}$, although there probably are a few peaks up to 1,60o m (detailed topographical maps of the area are unavailable). These mountain ranges are relatively isolated from the main Andean ridges. The nearest range of similar altitude is about $35 \mathrm{~km}$ to the south-west and the closest peaks above 1,400 $\mathrm{m}$ are about $75 \mathrm{~km}$ to the south of Pilón Lajas.

The vegetation of Pilón Lajas is quite varied, changing in relation to humidity, elevation and geological substrate. At Rurrenabaque $\left(14^{\circ} 26^{\prime} \mathrm{S} 68^{\circ} 31^{\prime} \mathrm{W}, 227 \mathrm{~m}\right)$, just north of Pilón Lajas (Figure 1), mean annual precipitation is 2,150 mm with a marked peak from November to April and a mean annual temperature of $25.8{ }^{\circ} \mathrm{C}$. The natural vegetation in about $38 \%$ of the reserve corresponds to evergreen tropical lowland forest. Higher elevations in Pilón Lajas, particularly those exposed to incoming clouds from the north-east, are somewhat cooler, receive considerably more precipitation and, above $c .1,000 \mathrm{~m}$, are frequently shrouded in mist. Here, forests are covered in epiphytic mosses, liverworts, ferns, bromeliads and orchids, and trees are often stunted.

Geologically, the area consists mainly of schists, loams and white sandstones of Tertiary age. Flat valley bottoms with mixed alluvial, nutrient-rich soils and good water supply are periodically flooded in the rainy season and support 3040 $\mathrm{m}$ tall forest with abundant palms (e.g. Iriartea deltoidea, Socratea exorrhiza), figs and leguminaceous trees. Gentle to fairly steep slopes are covered with forest of somewhat lower stature with up to 150 tree species and about 200 species of vascular epiphytes per ha (Seidel 1995, Smith and Killeen 1998, T. Krömer pers. com.). Above about 1,000 $\mathrm{m}$ the tree flora is dominated by the families Lauraceae, Leguminosae and Melastomataceae. Locally, there are dense stands of mahogany Swietenia macrophylla, many of which have been exploited in the last decades. Areas with white sand soils are very poor in nutrients and support a distinct and quite species-rich flora (Kessler 2001). Steep slopes, particularly at higher elevations, are characterized by unstable soils and frequent landslides and thus often support vegetation in different stages of succession, ranging from low, dense thickets to young, 10-15 $\mathrm{m}$ tall forest with many slender trees. The highest ridges often have shallow, leached soils and stunted, species-poor forest.

The overall picture emerging from the above combination of ecological factors is a striking heterogeneity of the vegetation that is conspicuous in the field (particularly from the air) and that forms the basis for the high biological species richness of the area. Botanically, individual vegetation types are of about average diversity compared with other Neotropical areas, but the high number of distinct vegetation types leads to an exceedingly diverse overall flora that contains 
numerous elements not known elsewhere in the Bolivian Andes (Smith and Killeen 1998, Kessler 2001).

\section{Results}

Currently, $5 \mathrm{O} 2$ bird species are known from Pilón Lajas (Appendix 2), more than one third of the 1,398 species reported in Bolivia (Hennessey et al. 2003). We believe that this includes at least $90 \%$ of the resident bird species in the reserve. Whereas 309 species (62\%) were recorded in the approximately 150,000 ha of lower tropical forest in Pilón Lajas, only 79 species were exclusively found in this zone. The lower tropical forest of Pilón Lajas appears quite species poor in comparison with other nearby lowland localities such as Alto Madidi, departamento (dpto.) La Paz, with 405 species (Parker and Bailey 1991) and the 5,00o ha Tambopata-Candamo Reserved Zone, Peru, with 572 species (Parker et al. 1994). This relatively low diversity may well be a result of the geographical position of Pilón Lajas on the southern edge of the Amazon basin where tropical lowland forest is limited to a narrow, $10-30 \mathrm{~km}$ wide belt along the Andean foothills.

Serranía Pilón is the most intensively studied and species-rich range within Pilón Lajas with 332 species, 48 of which have only been recorded in this area. Abundances of birds appear to be higher on Serranía Pilón than on comparable nearby ranges. Daily mixed-species flock encounters on serranías Bala and Cuchilla (Figure 1) as well as on Serranía Sadiri in Bolivia's Madidi National Park (ABH pers. obs.) ranged between one and three per day, whereas encounter rates on Serranía Pilón were between three and five per day. This is probably due to a higher level of precipitation in the area and the unusual topography of Serranía Pilón with several peaks, opposed to a typical single-peaked range, creating more habitat area between $600 \mathrm{~m}$ and $900 \mathrm{~m}$.

Upper tropical forest exists in Pilón Lajas only on serranías Bue, Chepete and Muchanes. All surveys in this habitat were restricted to Serranía Beu, where 246 bird species have been recorded, 46 of which were only found in upper tropical forest. Serranía Beu is the only area in Pilón Lajas with large patches of bamboo forest between 1,200 to 1,400 m; they cover an area of approximately 300 ha.

With respect to Arribas et al. (1995) and Remsen and Traylor (1989), the Pilón Lajas bird list includes 26 new records for dpto. Beni and three for dpto. La Paz (Appendix 2). However, these new records by no means represent true range extensions for the respective species. Bolivian departments are formed by arbitrary political borders that have little or no value in a habitat or conservation context. For example, about $85 \%$ of the area of the department of Beni is covered by pampas (savannah grasslands) whereas less than $1 \%$ contains hill tropical forest, from where most of our new records originated.

Pilón Lajas is located approximately $25 \mathrm{~km}$ south of a large expanse of pampas, and its northern and eastern border is formed by a main road. Through the years, the area has seen the establishment of pampas bird species as colonists have cleared forest. In Rurrenabaque, each year more open-country species are observed as the $30 \mathrm{~km}$ wide forest corridor between the town and the true pampas is being settled and destroyed. With continued forest clearing activities an increasing number of open-country species and austral migrants can be 
expected in open areas of Pilón Lajas with many of the former probably becoming resident along the edge of the reserve.

The majority of birds in Pilón Lajas increase their territorial singing in September/October. The full onset of the breeding season is linked with the beginning of the rainy season in November. During the rainy season there is a marked increase in insect abundance and more trees bear fruit. Local hunters claim that large mammals have more fat from February to April. We found reproductive evidence for 42 species (Appendix 2). Nest-building activity was observed between late July and mid-November (18 species), nesting activity (egg and hatchling stages) from mid-September to early November (nine species) and recent fledglings ( 15 species) between early October and mid-February (with two exceptions in mid-July).

\section{Mixed-species flocks}

$\mathrm{ABH}$ observed 45 mixed-species foraging flocks containing a total of 102 species in hill tropical forest $(500-900 \mathrm{~m})$. In the tropical lowlands, foraging flocks are often strictly separated into canopy and understorey flocks (e.g. Munn 1985, Jullien and Thiollay 1998). Due to the variable nature of hill tropical forest with steep slopes, landslides, cliffs, forest edges, stunted forest and tall forest, flock formations in Pilón Lajas were loosely categorized into three types: omnivorous tanager flocks, mid-canopy and understorey insectivorous mixed-species flocks.

The tanager canopy flocks were fast-moving, omnivorous flocks of the upper canopy based around Tangara species with Paradise Tanager Tangara chilensis as the nuclear species and Green-and-gold Tanager T. schrankii, Turquoise Tanager T. mexicana and Blue Dacnis Dacnis cayana as other characteristic species. Midcanopy insectivorous flocks ranged from $c .5 \mathrm{~m}$ above ground to well inside the highest canopy. These flocks were slower moving and sometimes large (c. 40 individuals) with most species foraging for insects. Characteristic species were Slate-throated Redstart Myioborus miniatus, Black-spotted Barbet Capito niger, Masked Tityra Tityra semifasciata, Guira Tanager Hemithraupis guira, Bronze-green Euphonia Euphonia mesochrysa, Bay-headed Tanager Tangara gyrola and Tropical Parula Parula pitiayumi. The nuclear species of understorey insectivorous flocks was Red-crowned Ant Tanager Habia rubica, with Buff-throated Foliage Gleaner Automolus ochrolaemus, Carmiol's Tanager Chlorothraupis carmioli, Chestnut-tailed Antbird Myrmeciza hemimelaena, McConnell's Flycatcher Mionectes macconnelli and Tawny-crowned Greenlet Hylophilus ochraceiceps as other characteristic species.

However, the majority of species in these flocks in hill tropical forest were not exclusive or even particular to any of the three flock types. This strongly contrasts with the rigidly organized flocks of Amazonian lowlands (Munn 1985, Jullien and Thiollay 1998) and supports the notion that conclusions on mixed-species flock structure and organization drawn from Neotropical lowland forests cannot be generalized to all tropical forests (Jullien and Thiollay 1998, Herzog et al. submitted MS).

\section{Species Accounts}

Orinoco Goose Neochen jubata

This Near Threatened species has been observed only once in Pilón Lajas at an 
unknown date in 1994 by F. Osorio and others, although indigenous people say the bird is sporadically seen on Rio Quiquebey. If a population still exists in Pilón Lajas, it will be in isolated regions away from hunters.

\section{Harpy Eagle Harpia harpyja}

This globally Near Threatened species has never been sighted in Pilón Lajas by trained observers. However, the Chiman and Moseten indigenous people are familiar with the bird and call it Bonij, but they do not have a name for the similar Crested Eagle Morphnus guianensis. ABH was shown a photo of a shot Harpy Eagle taken by an unknown tourist on the shore of the Beni River with in Pilón Lajas around 1970, proving that it did exist in the area, but the exact location of the dead bird was unclear. A Moseten elder reported that a family of Harpy Eagles exists east of S. Beu and described the species accurately as he said they ate one bird five years ago while hunting for White-bellied Spider Monkeys Ateles belzebuth. A Chiman hunter reported the location of a nest in Pilón Lajas south-west of the mouth of the Suapi River. We believe that a handful of Harpy Eagles still exists within Pilón Lajas, but that this population is threatened and restricted to areas with low human impact.

\section{Southern Horned Curassow Pauxi unicornis}

Parker (1989) gave the following account of this globally Vulnerable species from a 1989 survey in Serranía Pilón along the Caranavi-Yucumo road at the southeastern border of Pilón Lajas: "A man who has lived for one year near the road pass on the Serranía del Pilón accurately described this species and was certain that he had seen (eaten?) it in ridgetop forest several times. Called "mutum"." This record would appear to be a communication error as the name mutún locally refers to Razor-billed Curassow Mitu tuberosa.

None of the 22 expeditions in Pilón Lajas, including two to inaccessible, pristine and apparently suitable habitat for this species between serranías Beu and Chepete, has resulted in a single observation of this species. Likewise, numerous interviews including a survey of local indigenous knowledge by $\mathrm{ABH}$ and $\mathrm{A}$. Perry have failed to produce any indication that the species has ever occurred in the reserve. We believe that Pauxi unicornis does not exist in Pilón Lajas.

\section{Oilbird Steatornis caripensis}

Oilbird is a gregarious species, breeding colonially in caves. A single cave can hold up to 1,000 individuals (Thomas 1999; Duguid in litt. 2000). Only eight cave sites are known in Bolivia (ABH pers. obs.). Oilbirds could be threatened by habitat loss and scarcity of isolated breeding areas. On 4 November 1998, ABH and park guards observed 350 individuals leaving an inaccessible cave at $600 \mathrm{~m}$ on the edge of Serranía Chepete, beside the Beni River, during sunset and found fresh eggshells below the entrance to the cave.

\section{Lanceolated Monklet Micromonacha lanceolata}

One immature and two adults were observed for approximately 15 min on 9 December 1995 by ABH and A. Perry in the subcanopy $8 \mathrm{~m}$ above ground at 
1,150 m on Serranía Beu, dpto. La Paz. One adult fed a small unidentified insect to the immature and then perched $30 \mathrm{~cm}$ away while the second adult landed beside the immature and gave it a katydid-like insect longer than its bill. The immature clasped the insect in its bill for approximately 2 min before swallowing it. The immature's breast had less clearly defined black streaks and greyer mottling than both adults. These birds were observed on a steep forested slope with many successional stages from frequent landslides to dense forest patches with young trees. Another individual was observed in Pilón Lajas by A. Perry and R. Mitchell (pers. comm.) on the eastern edge of Serranía Beu at 1,00o $\mathrm{m}$ on 3 December 1996. These are the second and third observation of Lanceolated Monklet in Bolivia (Arribas et al. 1995). The first record was obtained by S. Cardiff and J.V. Remsen (in litt. 1998) at Cerro Asunta Pata ( $\left.15^{\circ} \mathrm{O}^{\prime} \mathrm{S} 68^{\circ} 28^{\prime} \mathrm{W}\right)$, dpto. La Paz, in 1993. The species was also observed in Carrasco National Park, dpto. Cochabamba, in July 1998 by A. Mee (in litt. 1998).

\section{Scaled Fruiteater Ampelioides tschudii}

Two birds, possibly a pair were noted repeatedly on Serranía Cuchilla, dpto. Beni, at $900 \mathrm{~m}$ in 1998 and 1999, especially by voice (MLNS 101799, 101819, 101874, 101877; Mayer 2000). On 17 November 1999 a male was observed by $\mathrm{ABH}$ and $\mathrm{M}$. Olivera feeding an immature an orange fruit of approximately 2.5 $\mathrm{cm}$ in diameter and regurgitated half bill-sized black fruits. Previously known in Bolivia only from Serranía Bellavista ( $38 \mathrm{~km} \mathrm{~N}$ Caranavi), dpto. La Paz (Parker et al. 1980), and Río Tuichi Valley, dpto. La Paz (Perry et al. 1997). ABH also recorded calls of one individual (MLNS 101845) at $900 \mathrm{~m}$ on Serranía Sadiri ( $14^{\circ} 13^{\prime} \mathrm{S} 67^{\circ} 56^{\prime} \mathrm{W}$ ) in Madidi National Park on 30 November 1999.

\section{Subtropical Pygmy Owl Glacidium parkeri}

C. König identified the first record of this species for Bolivia through recordings made by T.A. Parker during a 1979 expedition by the Museum of Natural Science, Louisiana State University, Baton Rouge, to Serranía Bellavista, dpto. La Paz (T.S. Schulenburg pers. comm.). B.M. Whitney (in litt. 2001) obtained the second record for Bolivia on Serranía Eslabon in Madidi National Park in August 1995 and the third in Pilón Lajas on Serranía Pilón at 700 m on 9 August 1997. Subsequently the species was recorded by ABH (MLNS 101656, 101689) several times on both the western $(1,300 \mathrm{~m})$ and eastern $(1,200 \mathrm{~m})$ slope of Serranía Beu and once at $750 \mathrm{~m}$ on Serranía Tequeje, Madidi National Park, on 6 April 2000.

\section{Bolivian Recurvebill Simoxenops striatus}

Until recently, this globally Vulnerable species was known from only three Bolivian localities (Parker et al. 1992), and Parker et al. (1996) considered it a high conservation and research priority. $\mathrm{ABH}$ observed and recorded several individuals on Serranía Beu at $800 \mathrm{~m}$ to 1,250 $\mathrm{m}$ from 17 to 24 September 1998 (MLNS 101637) and on Serranía Cuchilla at $800 \mathrm{~m}$ between 16 and 19 October 1998 (MLNS 101778; Mayer 2000), which represent two new localities for the species in Bolivia. Additionally, it has been found at three other new sites in dptos. La 
Paz, Cochabamba and Santa Cruz by SKH and MK in 1996 and 1997. Further details will be published elsewhere.

Yungas Antwren Myrmotherula grisea

A single female-plumaged bird of this globally Vulnerable Bolivian endemic was seen by SKH in an understorey mixed-species flock at c. $850 \mathrm{~m}$ on Serranía Pilón on 4 August 1997, which represents the only record for Pilón Lajas. The bird was characterized by unmarked wing-coverts and warm olivish-brown upperparts with a slight rufous tinge on wings and tail (in contrast to the all-grey upperparts of the female Grey Antwren M. menetriesii) and it resembled a female Yungas Antwren seen and tape-recorded by SKH together with a male (both singing) in Amboró National Park (dpto. Santa Cruz). Despite the presence of apparently suitable habitat within the species's elevational range, Yungas Antwren appears to be rare in Pilón Lajas.

\section{Phyllomyias sp.}

This undescribed species was first observed and tape-recorded in June 1989 at 850-900 m on Serranía Pilón along the Caranavi-Yucumo road (Parker et al. 1991), who tentatively identified the birds as Planalto Tyrannulets Phyllomyias fasciatus. However, they noted that their vocalizations were faster and higher pitched than those of birds in south-east Brazil and north-east Argentina and concluded that "the Serranía Pilón population may represent an undescribed form". On 2 June 1997 SKH tape-recorded three unidentified Phyllomyias tyrannulets in the canopy of humid forest edge at 1,150 m at Cerro Asunta Pata, dpto. La Paz $\left(15^{\circ} 3^{\prime} \mathrm{S} 68^{\circ} 28^{\prime} \mathrm{W}\right)$, and this recording was later identified with the help of B.M. Whitney as belonging to the same undescribed Phyllomyias taxon as recorded by Parker and Gell-Mann on Serranía Pilón (see Mayer 2000). On 3 September 1998, SKH and J.A. Balderrama collected two specimens at Cerro Asunta Pata and rediscovered the Serranía Pilón population at 850-1,000 m along the Caranavi-Yucumo road on 8 October 1998. Several tape-recordings from both localities show that the vocal differences noted by Parker et al. (1991) between Andean and south-east Brazilian populations are both consistent and significant (recordings of P. fasciatus from south-east Brazil provided by J. Mazar Barnett). A formal description of the species is currently in preparation (Herzog unpublished data).

It is noteworthy that despite the presence of apparently suitable hill tropical forest habitat on Serranías Beu, Cuchilla and Pilón the species has so far only been found at a single locality in Pilón Lajas, indicating that it may have a naturally patchy distribution and a small range.

\section{Shrike-like Cotinga Laniisoma elegans}

This globally Vulnerable species was observed by ABH on 22 September 199915 $\mathrm{m}$ above the ground on the northern side of Serranía Beu in steep-sloped hill tropical forest $(850 \mathrm{~m})$. This is only the second observation for Bolivia of this poorly known species (Hennessey et al. 2003). 


\section{Scarlet Tanager Piranga olivacea}

This Nearctic-Neotropical migrant has suffered population declines attributed to habitat loss in its wintering range (McNair and Escobar 1993). However, its non-breeding distribution in South America is poorly known (Parker et al. 1996). ABH observed this species on Serranía Pilón in November 1996 and February 1997 and 1998, on Serranía Cuchilla in November 1999, and on Serranía Sadiri in Madidi National Park in November 1999. Wintering males were identified by their contrasting black wings in November, and by the splotchy breeding plumage in February. The identification of females was assumed through their presence with Scarlet Tanager males, which in February consisted of associating groups of 5-8 individuals. The species was fairly common in all years and areas. For example, on a total of seven days on Serranía Pilón during the months stated above, ABH daily observed between two and seven individuals in non-breeding plumage in mid-canopy foraging flocks of hill tropical forest $(600-900 \mathrm{~m})$. We believe these records from serranías Pilón, Cuchilla and Sadiri indicate that a considerable portion of the species' population winters along the humid foothills of the Bolivian Andes. This habitat is still largely unaltered in Bolivia; hence, a decline due to habitat loss is probably largely caused by the alteration of habitat in the breeding range or along the migration route of Scarlet Tanager.

\section{Buff-rumped Warber Basileuterus fulvicauda}

J. Ohlson (pers comm.) observed several individuals on Serranía Bala from 25 to 28 April 1999 and recorded one (Mayer 2000). Observations and recordings (MLNS 87814 and 101816) by ABH and SKH on serranías Pilón and Cuchilla have exclusively been of the similar River Warbler Basileuterus rivularis. The song of both species is difficult to differentiate. Thus, both species occur within at most $30 \mathrm{~km}$ of each other in Pilón Lajas, but the actual contact zone as well as the degree of sympatry and hybridization (if any) remain to be determined.

\section{Discussion}

Recorded from Pilón Lajas are four species of Bolivian endemics, eight species of range-restricted endemics (Stattersfield et al. 1998), 28 zoogeographical regional endemics (Stotz et al. 1996), three Vulnerable and three Near Threatened species (BirdLife International 2000), and four High Conservation Priority and 32 Medium Conservation Priority species (Parker et al. 1996) (Appendix 2, Table 2). Of the High and Medium Conservation Priority species, eight have their centre of abundance in lower tropical $(<500 \mathrm{~m})$, nine in hill tropical $(500-900 \mathrm{~m}), 17$ in upper tropical (900-1,600 m) and two in middle tropical $(1,600-2,600 \mathrm{~m})$ forest. All High Conservation Priority species in Pilón Lajas appear to be rare, with only one record per species, except for Simoxenops striatus. These apparently extremely low population densities imply that optimal conditions for these species may not be met in Pilón Lajas despite the presence of apparently suitable habitat and that the reserve alone cannot warrant their effective conservation in Bolivia.

Pilón Lajas protects a healthy part of the Bolivian and Peruvian lower Yungas EBA (054) (Stattersfield et al. 1998). Eight range-restricted species have been 
Table 2. Species in Pilón Lajas, Bolivia, listed as High and Medium Conservation Priorities by Parker et al. (1996) and Vulnerable $\left(^{*}\right)$ or Near Threatened $(* *)$ by BirdLife International (2000). Research priority and centre of abundance after Parker et al. (1996). Numbers in parentheses refer to the number of records.

\begin{tabular}{|c|c|c|c|c|}
\hline Species & $\begin{array}{l}\text { Conservation } \\
\text { priority }\end{array}$ & $\begin{array}{l}\text { Research } \\
\text { priority }\end{array}$ & $\begin{array}{l}\text { Centre of } \\
\text { abundance }\end{array}$ & $\begin{array}{l}\text { Pilón Lajas } \\
\text { abundance }\end{array}$ \\
\hline \multicolumn{5}{|l|}{ Orinoco Goose ${ }^{* *}$} \\
\hline Neochen jubata & High & High & Lower tropical & Very rare (1) \\
\hline $\begin{array}{l}\text { Fasciated Tiger Heron } \\
\text { Tigrisoma fasciatum }\end{array}$ & Medium & High & Hill tropical & Very rare $(2)$ \\
\hline $\begin{array}{l}\text { Solitary Eagle } \\
\text { Harpyhaliaetus solitarius }\end{array}$ & Medium & Medium & Upper tropical & Very rare $(2)$ \\
\hline $\begin{array}{l}\text { Harpy Eagle** } \\
\text { Harpia harpyja }\end{array}$ & Medium & High & Lower tropical & Very rare (?) \\
\hline $\begin{array}{l}\text { Red-throated Caracara } \\
\text { Ibycter americanus }\end{array}$ & Medium & Medium & Lower tropical & Fairly common \\
\hline $\begin{array}{l}\text { Maroon-chested Ground Dove } \\
\text { Claravis mondetoura }\end{array}$ & Medium & Medium & Middle montane & Very rare (1) \\
\hline $\begin{array}{l}\text { Blue-and-yellow Macaw } \\
\text { Ara ararauna }\end{array}$ & Medium & Medium & Lower tropical & Fairly common \\
\hline $\begin{array}{l}\text { Military Macaw* } \\
\text { Ara militaris }\end{array}$ & Medium & Medium & Upper tropical & Uncommon \\
\hline $\begin{array}{l}\text { Red-billed Parrot } \\
\text { Pionus sordidus }\end{array}$ & Medium & Medium & Upper tropical & Uncommon \\
\hline $\begin{array}{l}\text { Rufous-vented Ground Cuckoo } \\
\text { Neomorphus geoffroyi }\end{array}$ & Medium & Medium & Lower tropical & Very rare (1) \\
\hline $\begin{array}{l}\text { Band-bellied Owl } \\
\text { Pulsatrix melanota }\end{array}$ & Medium & Medium & Hill tropical & Fairly common \\
\hline $\begin{array}{l}\text { Silky-tailed Nightjar } \\
\text { Caprimulgus sericocaudatus }\end{array}$ & Medium & Medium & Lower tropical & Very rare (1) \\
\hline $\begin{array}{l}\text { White-browed Hermit } \\
\text { Phaethornis stuarti }\end{array}$ & Medium & Medium & Hill tropical & Very rare (1) \\
\hline $\begin{array}{l}\text { Rufous-crested Coquette } \\
\text { Lophornis delattrei }\end{array}$ & Medium & Medium & Upper tropical & Very rare (1) \\
\hline $\begin{array}{l}\text { Many-spotted Hummingbird } \\
\text { Taphrospilus hypostictus }\end{array}$ & Medium & Medium & Hill tropical & Very rare (1) \\
\hline $\begin{array}{l}\text { Crested Quetzal } \\
\quad \text { Pharomachrus antisianus }\end{array}$ & Medium & Medium & Upper tropical & Fairly common \\
\hline $\begin{array}{l}\text { Ash-browed Spinetail } \\
\text { Cranioleuca curtata }\end{array}$ & Medium & Medium & Upper tropical & Rare \\
\hline $\begin{array}{l}\text { Bolivian Recurvebill* } \\
\text { Simoxenops striatus }\end{array}$ & High & High & Hill tropical & Uncommon \\
\hline $\begin{array}{l}\text { Yungas Antwren* } \\
\text { Myrmotherula grisea }\end{array}$ & High & High & Hill tropical & Very rare (1) \\
\hline $\begin{array}{l}\text { Rough-legged Tyrannulet } \\
\text { Phyllomyias burmeisteri }\end{array}$ & Medium & Medium & Hill tropical & Uncommon \\
\hline $\begin{array}{l}\text { Spectacled Bristle Tyrant } \\
\text { Phylloscartes orbitalis }\end{array}$ & Medium & Medium & Hill tropical & Uncommon \\
\hline $\begin{array}{l}\text { White-bellied Pygmy Tyrant } \\
\text { Myiornis albiventris }\end{array}$ & Medium & Medium & Hill tropical & Fairly common \\
\hline $\begin{array}{l}\text { Yungas Tody Tyrant } \\
\text { Hemitriccus spodiops }\end{array}$ & Medium & Medium & Upper tropical & Common \\
\hline $\begin{array}{l}\text { Buff-throated Tody Tyrant } \\
\text { Hemitriccus rufigularis }\end{array}$ & Medium & Medium & Upper tropical & Rare \\
\hline $\begin{array}{l}\text { Shrike-like Cotinga } \\
\text { Laniisoma elegans }\end{array}$ & High & High & Upper tropical & Very rare (1) \\
\hline
\end{tabular}


Table 2. Continued.

\begin{tabular}{|c|c|c|c|c|}
\hline Species & $\begin{array}{l}\text { Conservation } \\
\text { priority }\end{array}$ & $\begin{array}{l}\text { Research } \\
\text { priority }\end{array}$ & $\begin{array}{l}\text { Centre of } \\
\text { abundance }\end{array}$ & $\begin{array}{l}\text { Pilón Lajas } \\
\text { abundance }\end{array}$ \\
\hline $\begin{array}{l}\text { Scaled Fruiteater } \\
\text { Ampelioides tschudii }\end{array}$ & Medium & Medium & Upper tropical & Uncommon \\
\hline $\begin{array}{l}\text { Andean Cock-of-the-Rock } \\
\text { Rupicola peruviana }\end{array}$ & Medium & Medium & Upper tropical & Fairly common \\
\hline $\begin{array}{l}\text { Orange-eared Tanager } \\
\text { Chlorochrysa calliparaea }\end{array}$ & Medium & Medium & Upper tropical & Very rare (1) \\
\hline $\begin{array}{l}\text { Pale-winged Trumpeter } \\
\text { Psophia leucoptera }\end{array}$ & Medium & Low & Lower tropical & Rare \\
\hline $\begin{array}{l}\text { Red-and-green Macaw } \\
\text { Ara chloroptera }\end{array}$ & Medium & Low & Lower tropical & Fairly common \\
\hline $\begin{array}{l}\text { Upland Antshrike } \\
\text { Thamnophilus aroyae }\end{array}$ & Medium & Low & Upper tropical & Fairly common \\
\hline $\begin{array}{l}\text { Scaled Antpitta } \\
\text { Grallaria guatimalensis }\end{array}$ & Medium & Low & Upper tropical & Rare \\
\hline $\begin{array}{l}\text { Slaty Gnateater } \\
\text { Conopophaga ardesiaca }\end{array}$ & Medium & Low & Upper tropical & Uncommon \\
\hline $\begin{array}{l}\text { Slaty Tanager } \\
\text { Creurgops dentata }\end{array}$ & Medium & Low & Middle montane & Very rare (1) \\
\hline $\begin{array}{l}\text { Bronze-green Euphonia } \\
\text { Euphonia mesochrysa }\end{array}$ & Medium & Low & Upper tropical & Common \\
\hline $\begin{array}{l}\text { Golden-eared Tanager } \\
\text { Tangara chrysotis }\end{array}$ & Medium & Medium & Upper tropical & Very rare (2) \\
\hline
\end{tabular}

recorded of a potential 13 species found in Bolivia. The range-restricted endemism of Serranía Beu demonstrated the area to be a potential Important Bird Area. Serranía Beu and the surrounding area are sufficiently difficult to access through climbing, long hikes and the lack of road access, that the areas may be easily protected from habitat destruction through local population pressure.

Serranía Pilón is an important area in Pilón Lajas to protect foothill-specialized species. The foothill forest, though not considered specialization enough to deserve EBA status, is a unique ecosystem that deserves conservation attention. Through high levels of precipitation and the mix between lowland and Yungas species, these areas tend to be the richest sites of avian diversity on the planet. With no avifaunal data from Serranía del Tigre ( $\left.13^{\circ} 38^{\prime} \mathrm{S} 68^{\circ} 4 \mathrm{o}^{\prime} \mathrm{W}\right)$, mostly outside the Madidi National Park border, Serranía Pilón is the richest area of foothill forest in Bolivia. The site, with a main road travelling through the area, also contains ecotourism-sustainable development possibilities.

Pilón Lajas has common borders with Madidi National Park to the north-west and with the Moseten Indigenous Area, which applies sustainable forestry practices, to the south. However, the north- and south-eastern borders of Pilón Lajas are adjacent to major roads that have enabled human settlement on the park boundaries, posing a serious future threat to the reserve. Pilón Lajas is trying to counteract this encroachment with two park guard stations along both roads and the implementation of public education programmes. Recently a sustainable ecotourism project has been designed with a local indigenous group at the mouth of Rio Quiquebey.

Together with Madidi National Park and the directly adjacent Bahuaja Sonene 
National Park in south-eastern Peru, Pilón Lajas forms part of a unique protected area system of more than 3.5 million ha. It further represents a vital link towards foothill and montane forest areas further south and plays an important role in the establishment of biological corridors along the eastern Andean slope in Bolivia.

\section{Acknowledgements}

We would like to thank Veterinarians Without Frontiers and the British, Dutch and Swiss Governments for their support and efforts to protect this special area of the earth and to support our insistence for more field investigations. $\mathrm{ABH}$ would like to especially thank Sjoerd Mayer for his meticulous review of Pilón Lajas sound recordings, the use of his pre-release CD-ROM Birds of Bolivia 2, and the hundreds of email messages on "mystery" sounds, queries and bird sound discussions. We are grateful to Bret M. Whitney for his assistance with Pilón Lajas research and for his time and patience with his remarkable identifications of "mystery" sounds that no one else could identify. ABH is most appreciative for the donations of tapes and equipment by Greg Budney at Cornell's Macaulay Library of Natural Sounds. In addition, we thank Doug Stotz, Tom Schulenberg and Jon Fjeldsa for their informative answers to the many questions involving Pilón Lajas research. Financial support was provided to ABH by Veterinarians Without Frontiers as well as the British, Dutch and Swiss Governments, and to MK by the Deutsche Forschungsgemeinschaft.

Appendix 1. Ornithological surveys in Pilón Lajas, Bolivia.

\begin{tabular}{|c|c|c|c|}
\hline Researchers & Site & Date & $\begin{array}{l}\text { Period } \\
\text { (days) }\end{array}$ \\
\hline T.A. Parker & S. Pilón (6oo-1,00o m) & June 1989 & 4 \\
\hline $\begin{array}{l}\text { F. Osorio, S. Barrera, } \\
\text { J.F. Guerra, J. } \\
\text { Sarmiento, L. Villalba }\end{array}$ & $\begin{array}{l}\text { Quiquibey and Suapi rivers and } \\
\text { Colorado }(350-500 \mathrm{~m})\end{array}$ & June 1993 & 10 \\
\hline $\mathrm{ABH}$ & Suapi River (450 m) & November 1995 & 4 \\
\hline A. Perry, ABH & S. Beu (western end, $700-1,300 \mathrm{~m}$ ) & December 1995 & 7 \\
\hline F. Sagot & Colorado $(350-400 \mathrm{~m})$ & June 1996 & 6 \\
\hline ABH, R. Silva & Colorado to Quiquibey (350-400 m) & July 1996 & 7 \\
\hline $\mathrm{ABH}$ & S. Bala $(400-700 \mathrm{~m})$ & October 1996 & 3 \\
\hline ABH, R. Mitchell & S. Bala $(500-900 \mathrm{~m})$ & November 1996 & 4 \\
\hline $\mathrm{ABH}$ & S. Pilón (6oo-1,00o m) & November 1996 & 7 \\
\hline A. Perry, R. Mitchell & S. Zaguacales (350-700 m) & November 1996 & 6 \\
\hline A. Perry, R. Mitchell & S. Beu (eastern end, $600-1,400 \mathrm{~m}$ ) & December 1996 & 11 \\
\hline $\mathrm{ABH}$ & S. Pilón $(700-750 \mathrm{~m})$ & February 1997 & 1 \\
\hline $\mathrm{ABH}$ & S. Pilón (500-1,000 m) & April 1997 & 5 \\
\hline $\mathrm{ABH}$ & S. Pilón $(600-1,000 \mathrm{~m})$ & June 1997 & 7 \\
\hline SKH, MK & S. Pilón (450-1,00o m) & July 1997 & 18 \\
\hline B.M. Whitney, ABH & S. Pilón $(400-750 \mathrm{~m})$ & August 1997 & 3 \\
\hline $\mathrm{ABH}$ & S. Pilón $(350-1,000 \mathrm{~m})$ & February 1998 & 11 \\
\hline $\mathrm{ABH}$ & S. Beu (western end, 1,200-1,450 m) & September 1998 & 7 \\
\hline $\mathrm{ABH}$ & S. Beu (western end, $800-1,000 \mathrm{~m}$ ) & September 1998 & 5 \\
\hline SKH, J.A. Balderrama & S. Pilón $(450-500 \mathrm{~m})$ & October 1998 & 4 \\
\hline $\mathrm{ABH}$ & S. Cuchilla (500-900 m) & October 1998 & 6 \\
\hline $\mathrm{ABH}$ & S. Cuchilla (700-90o m) & November 1999 & 12 \\
\hline
\end{tabular}


A.B. Hennessey et al.

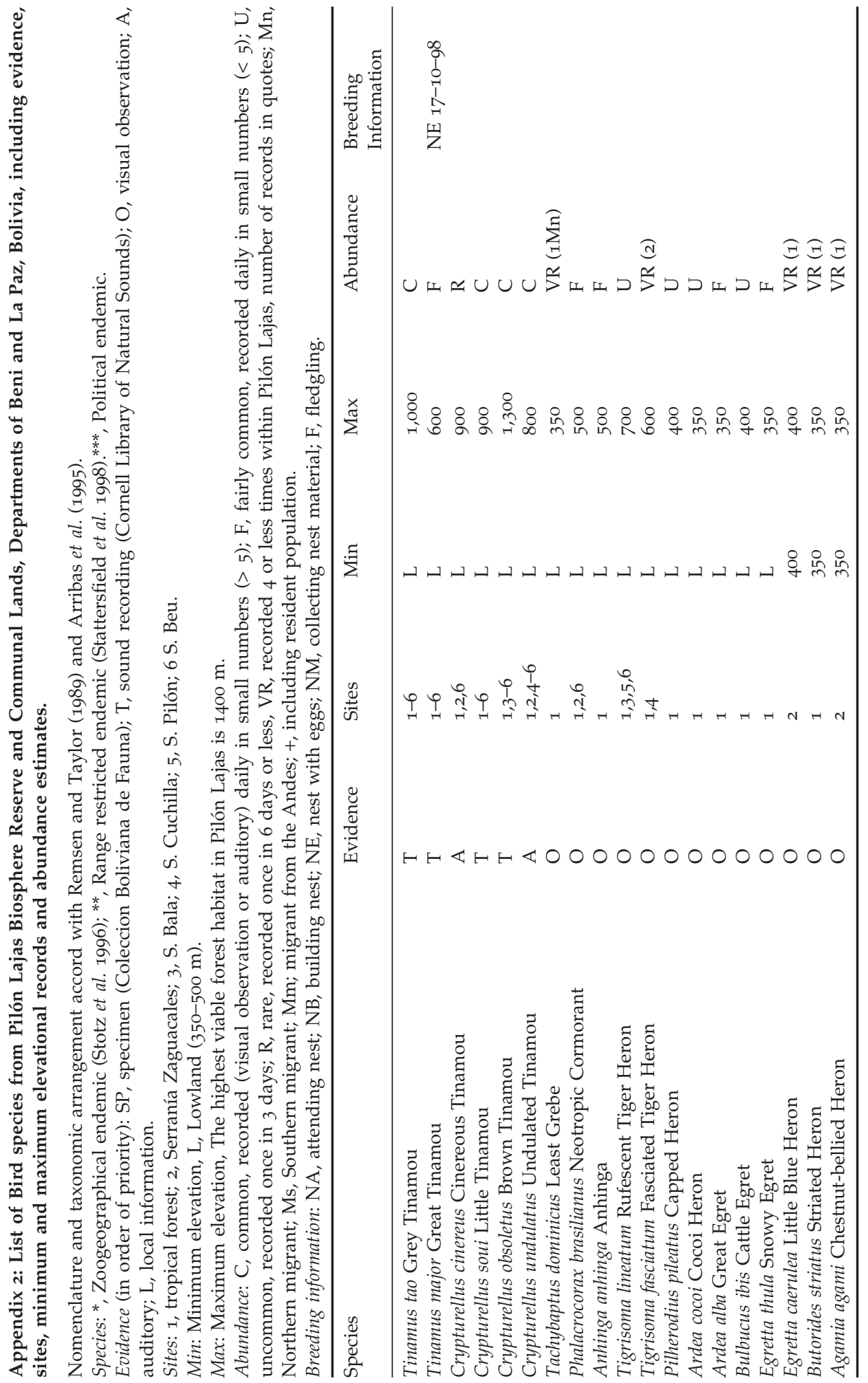




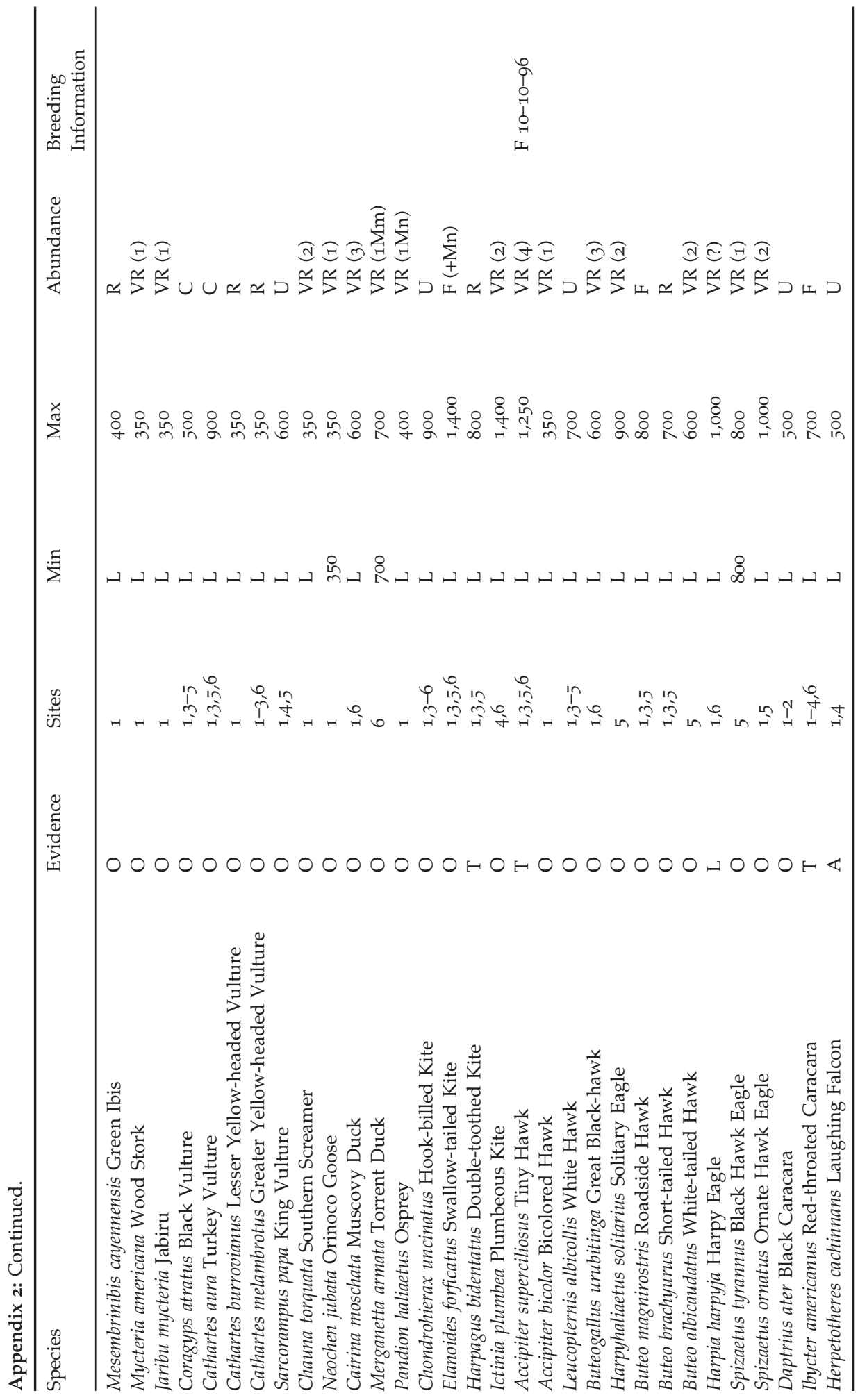




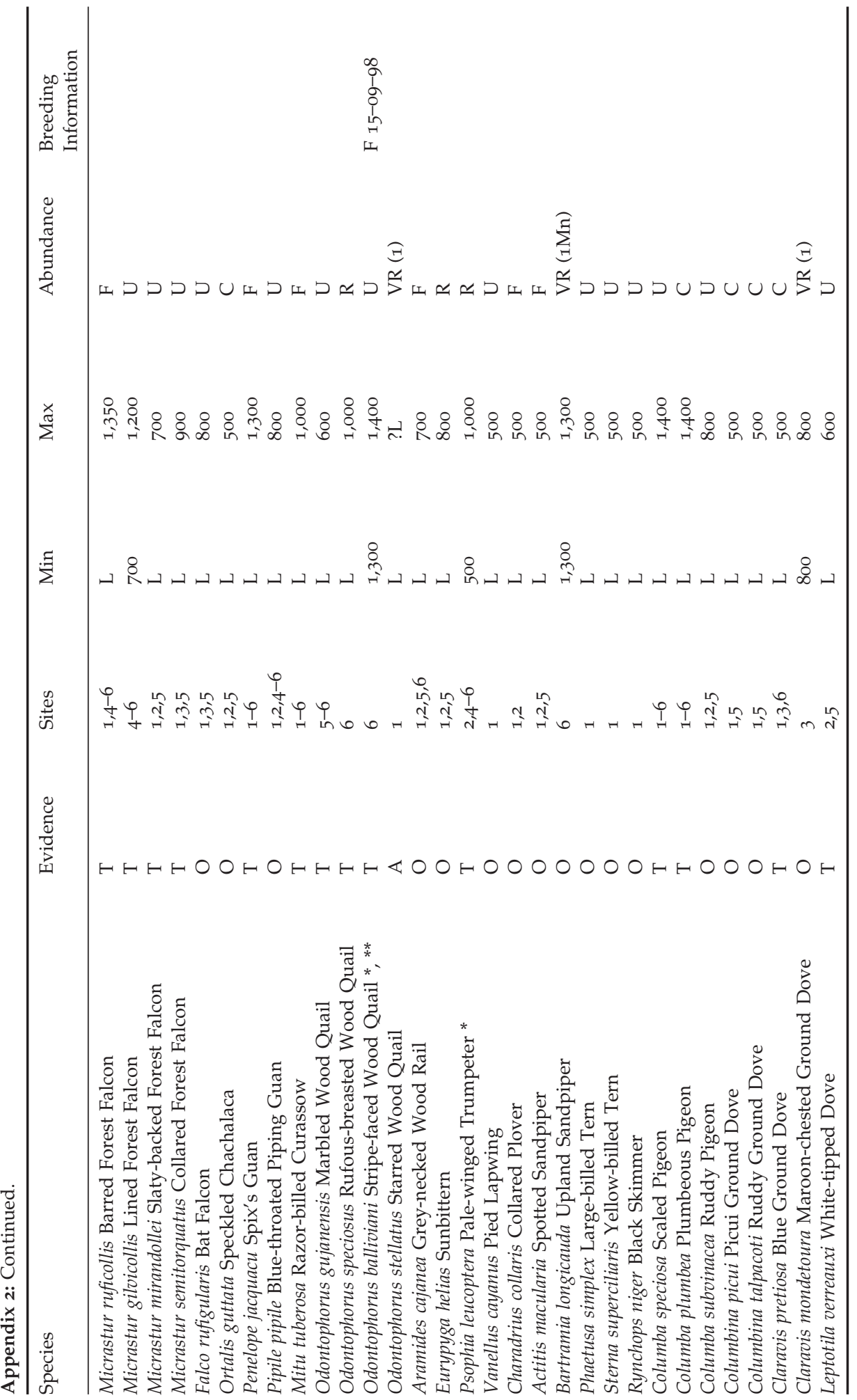




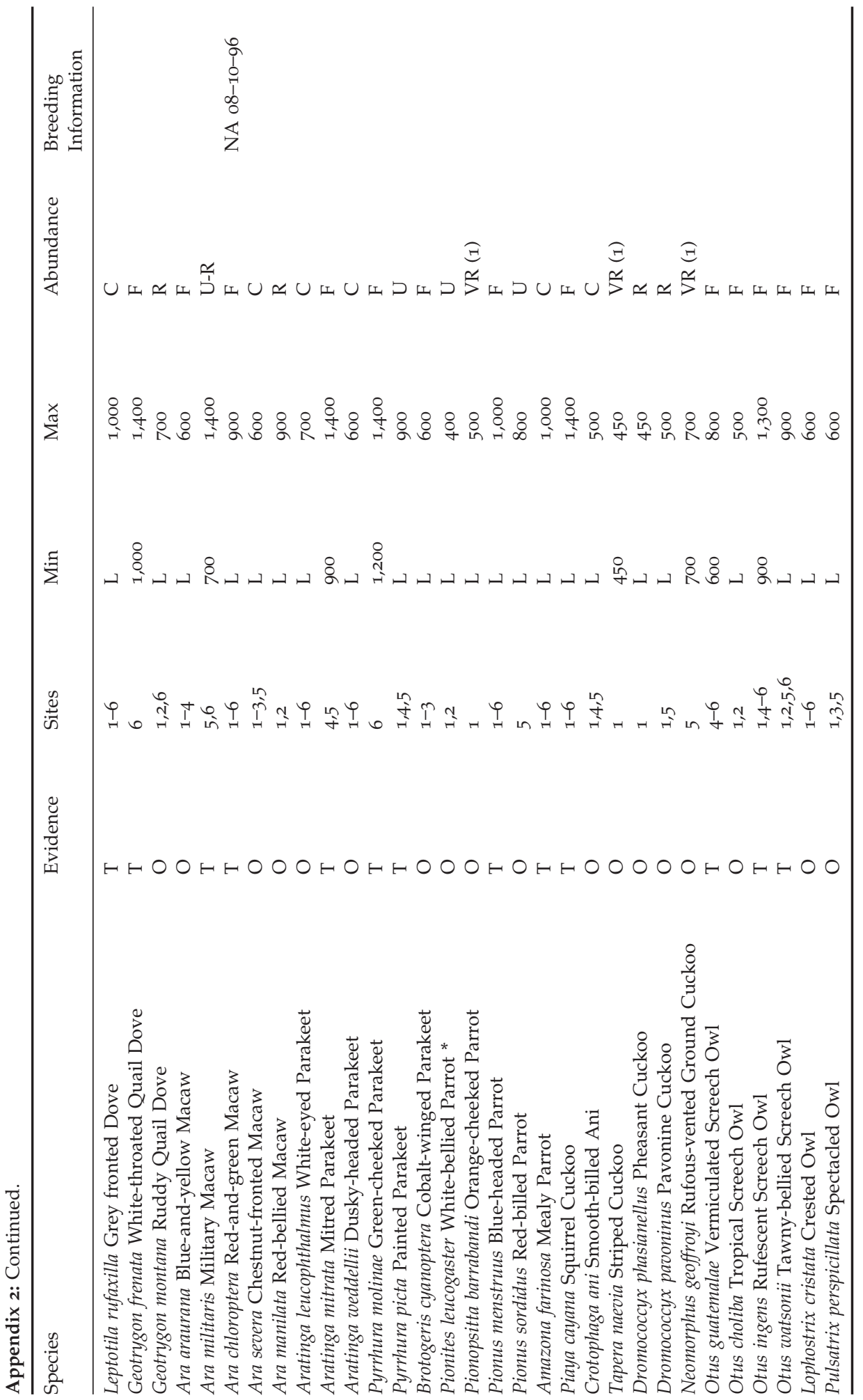




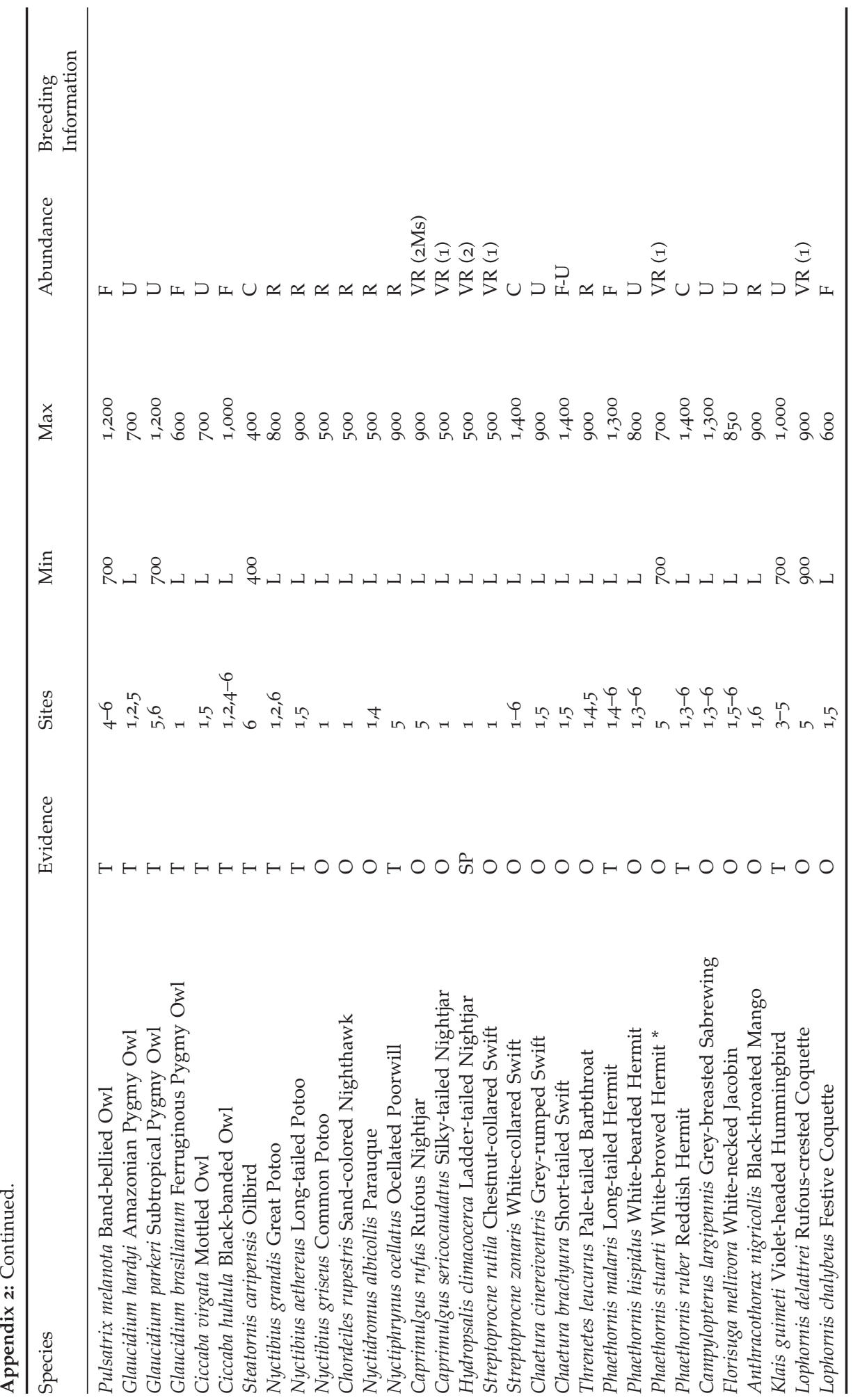




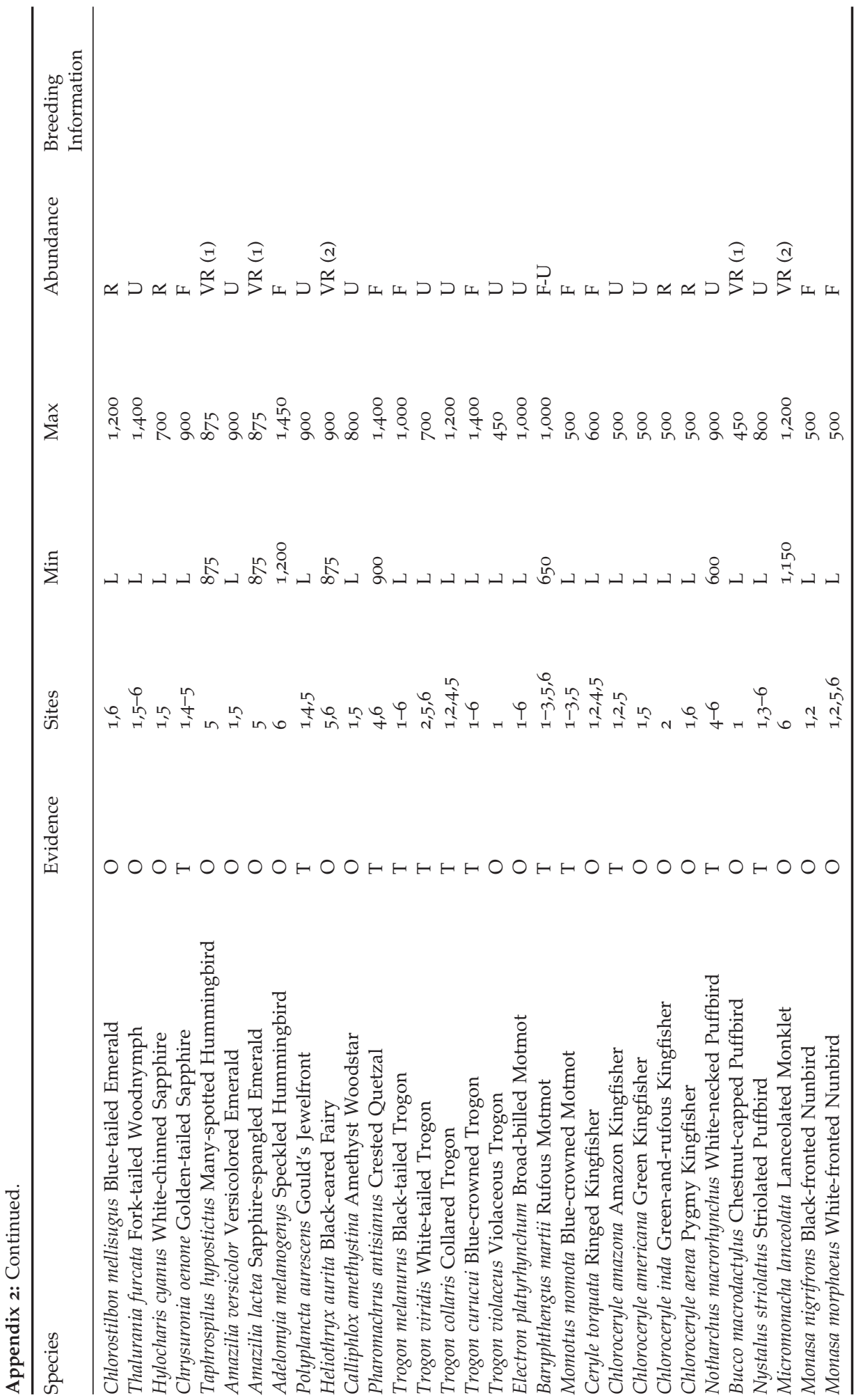




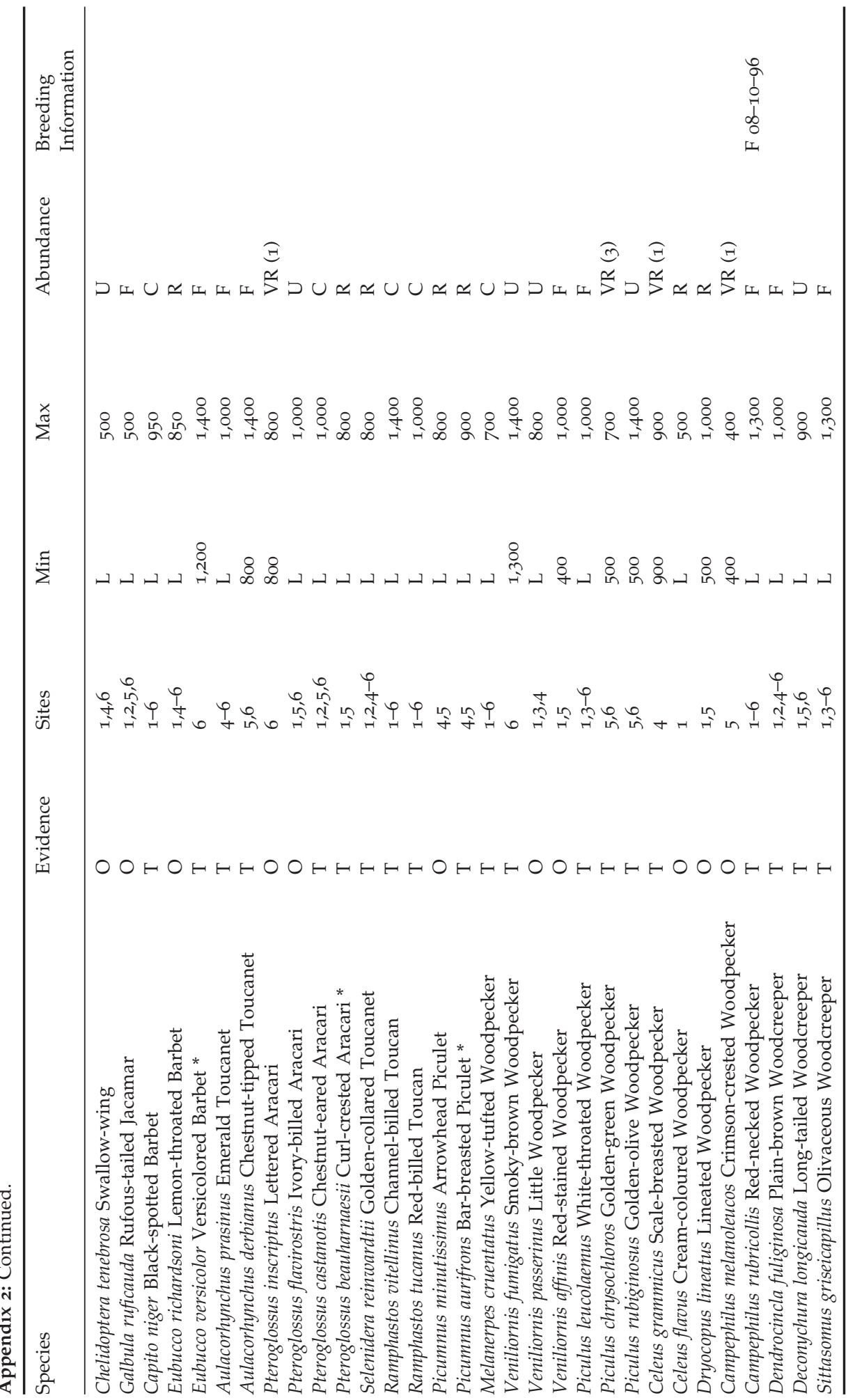




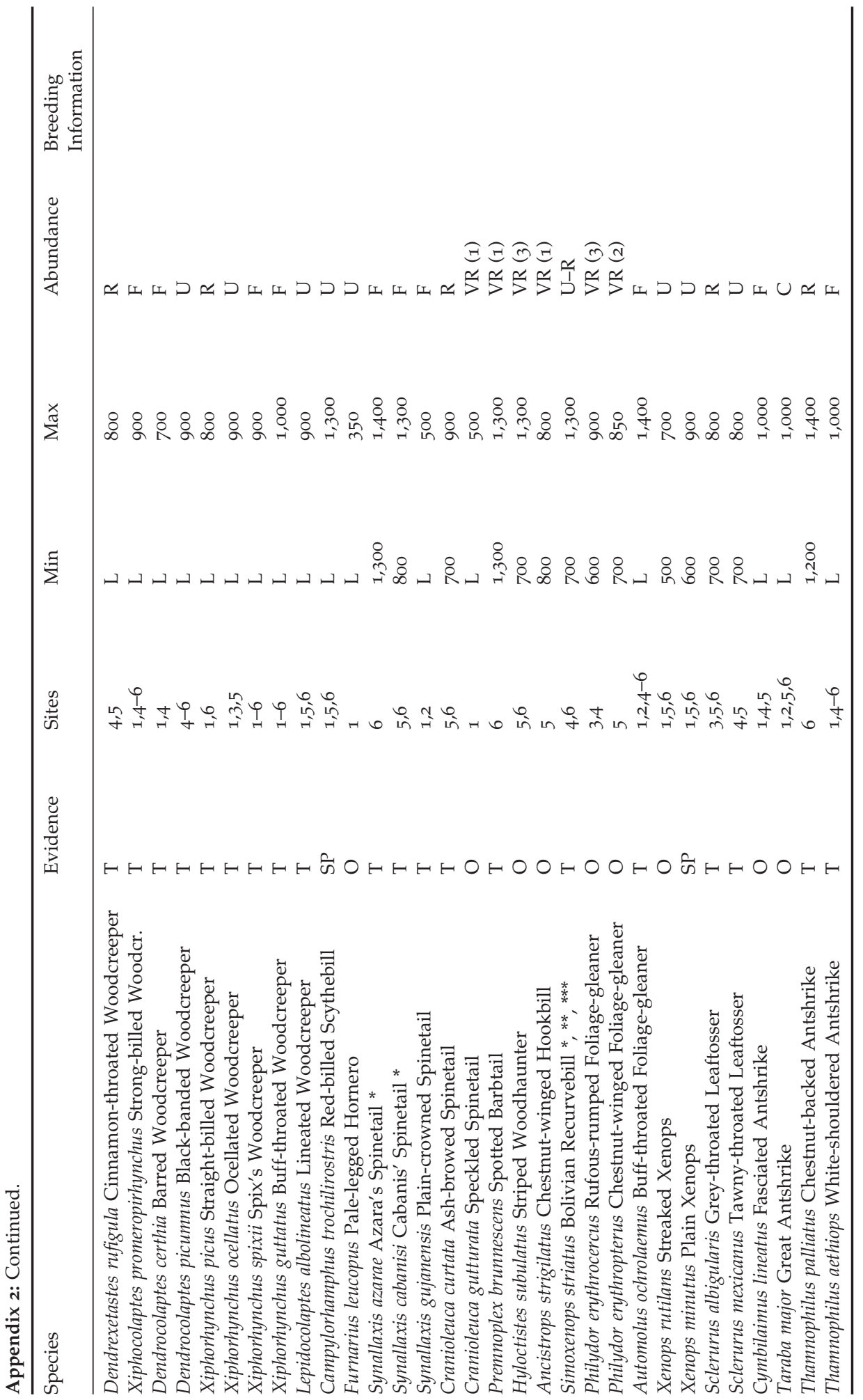


A.B. Hennessey et al.

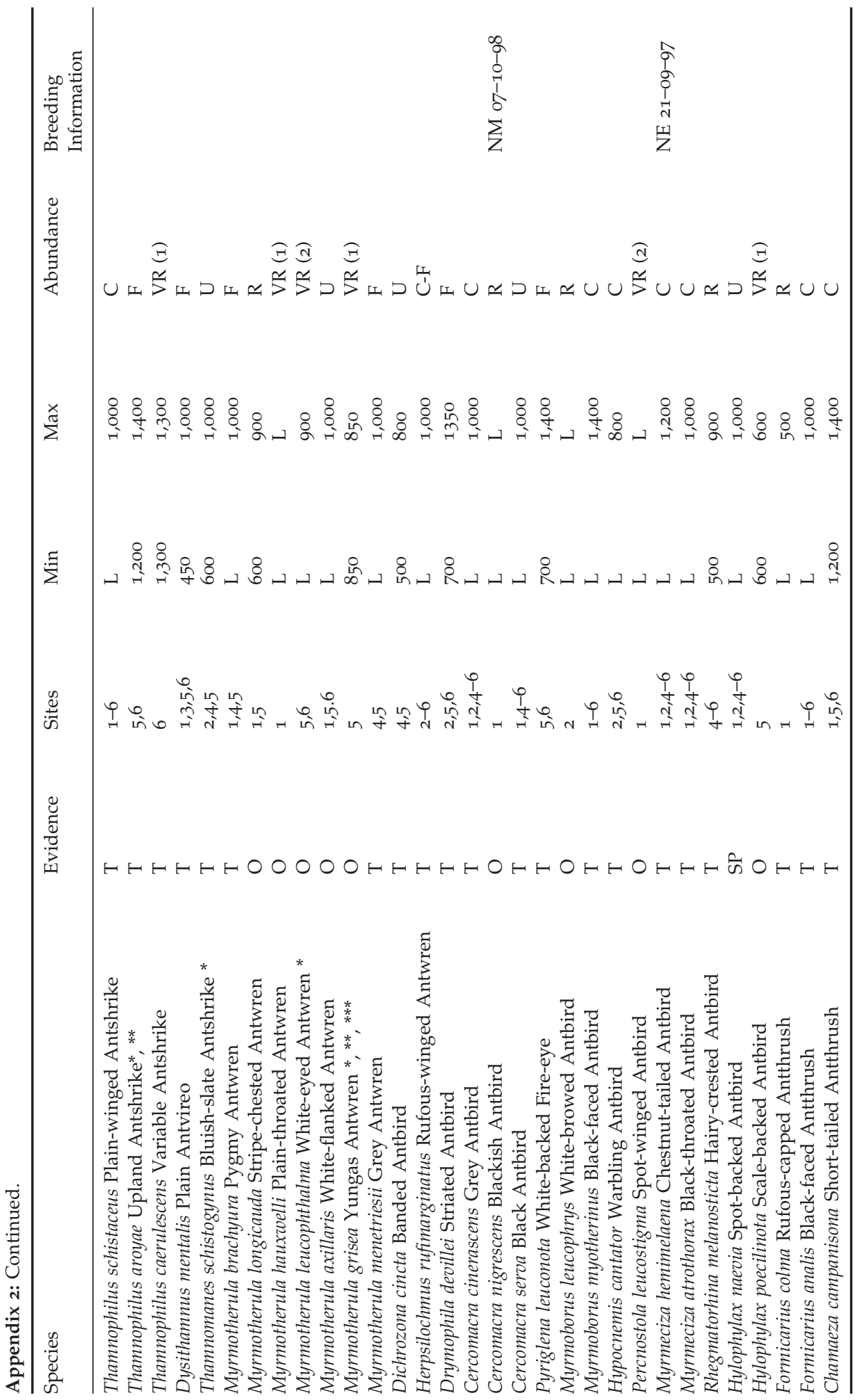




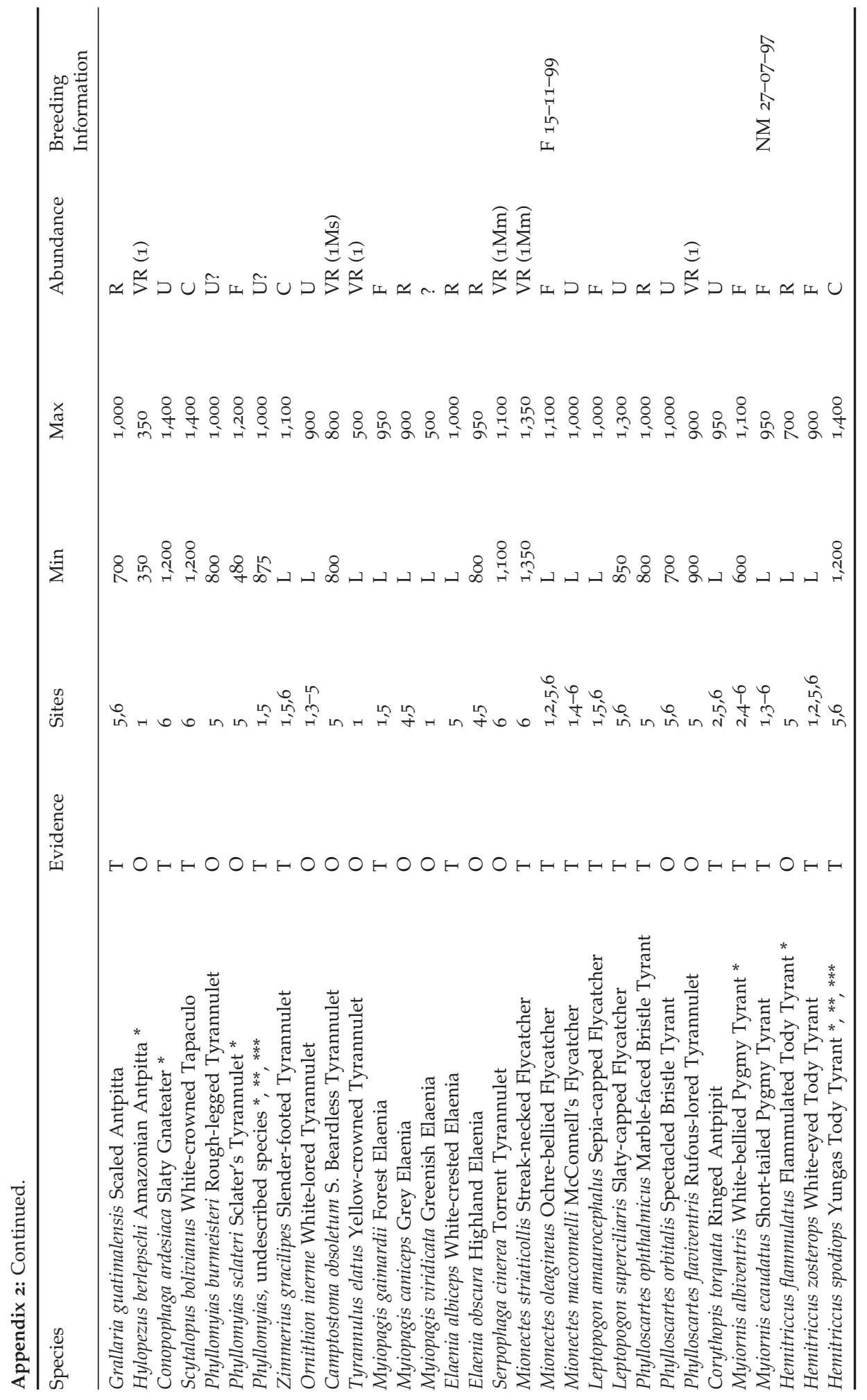


A.B. Hennessey et al.

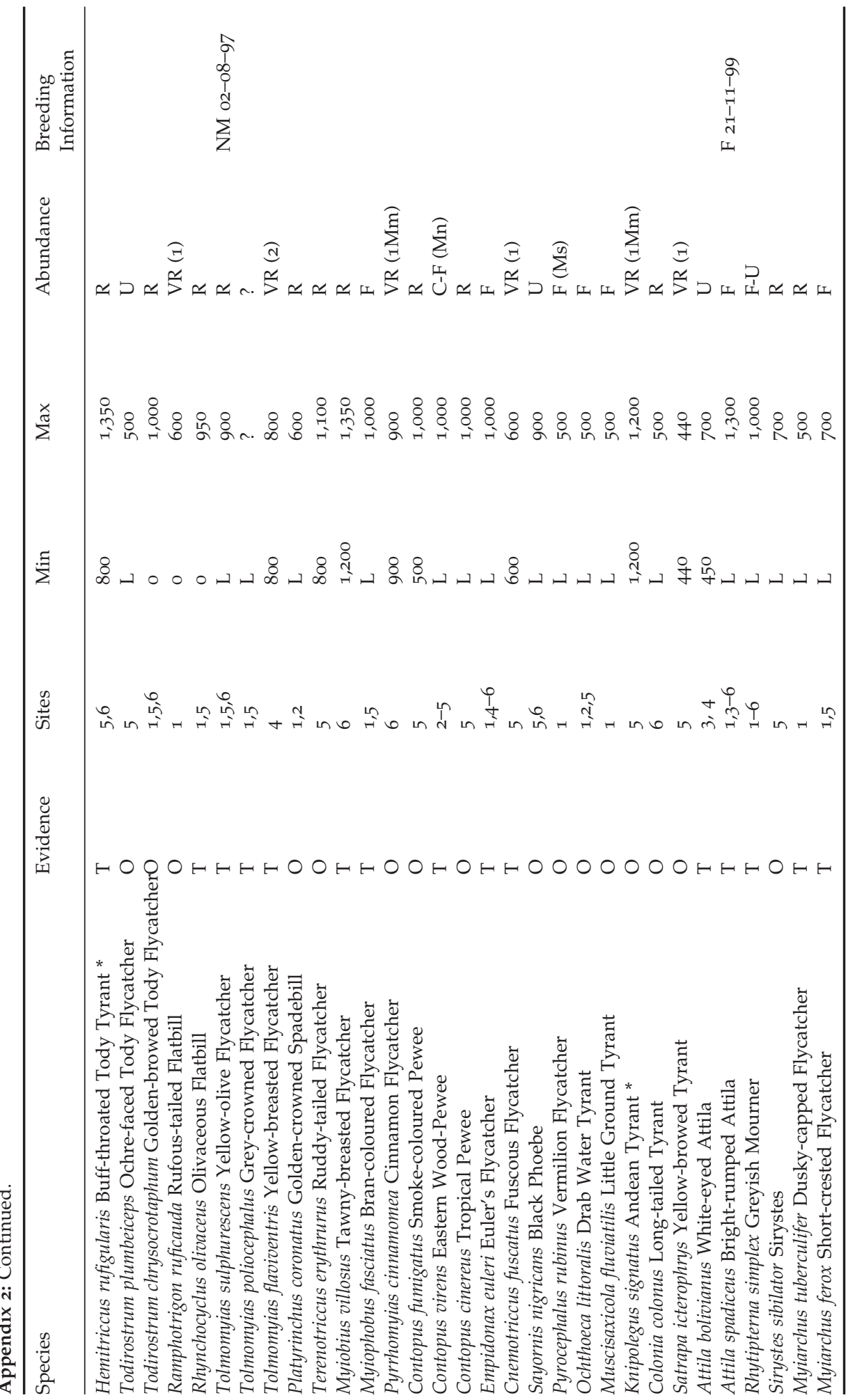




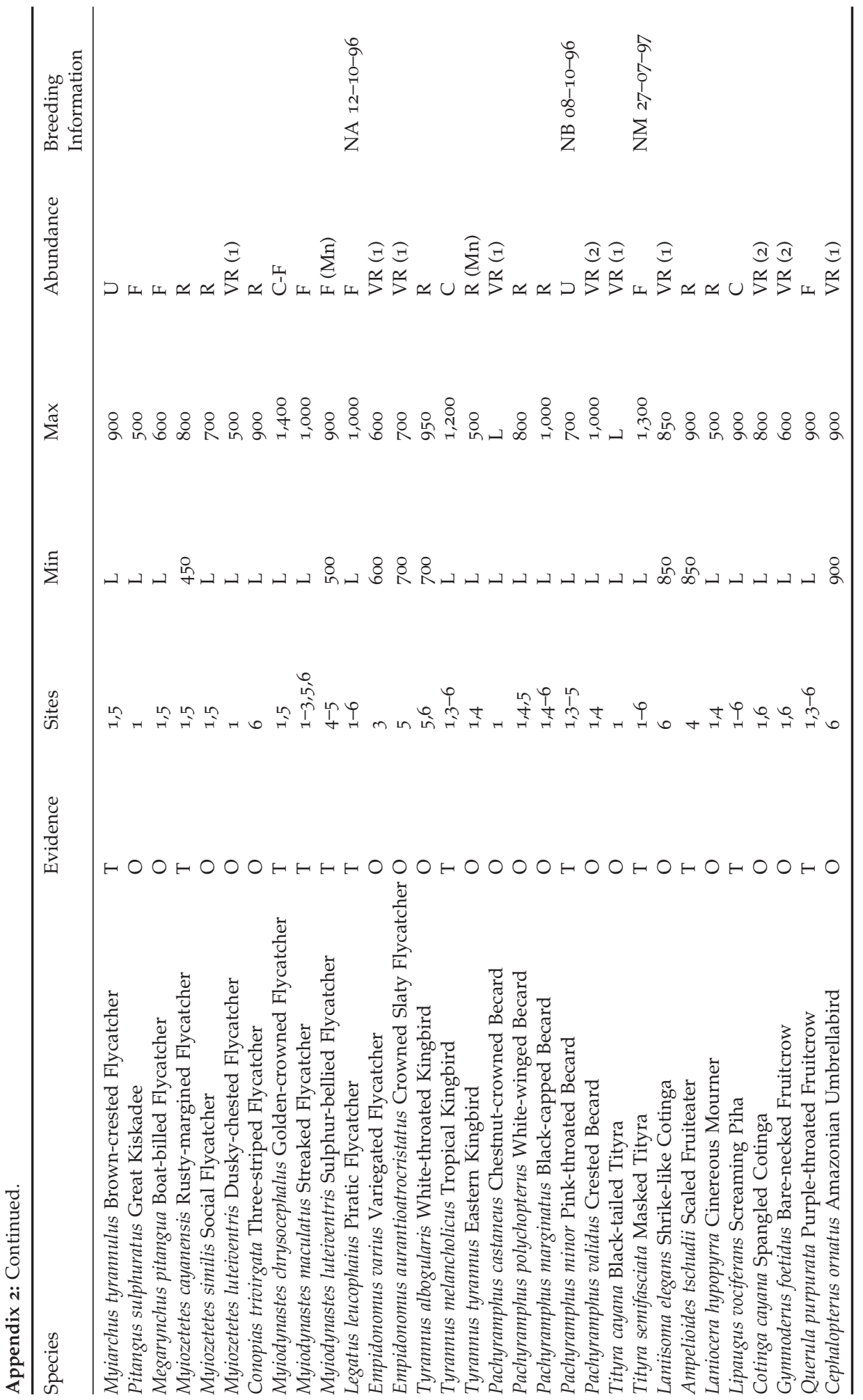




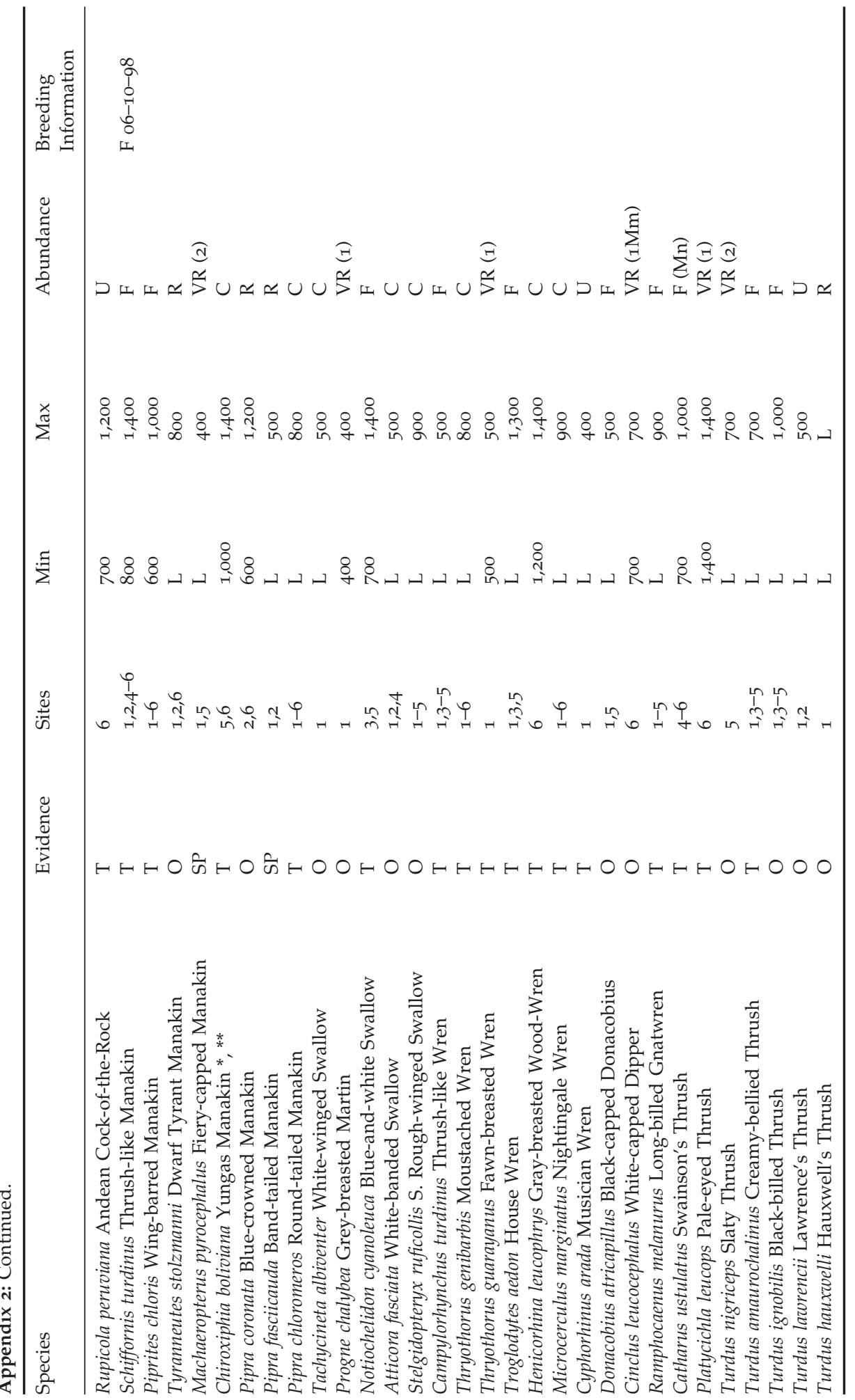




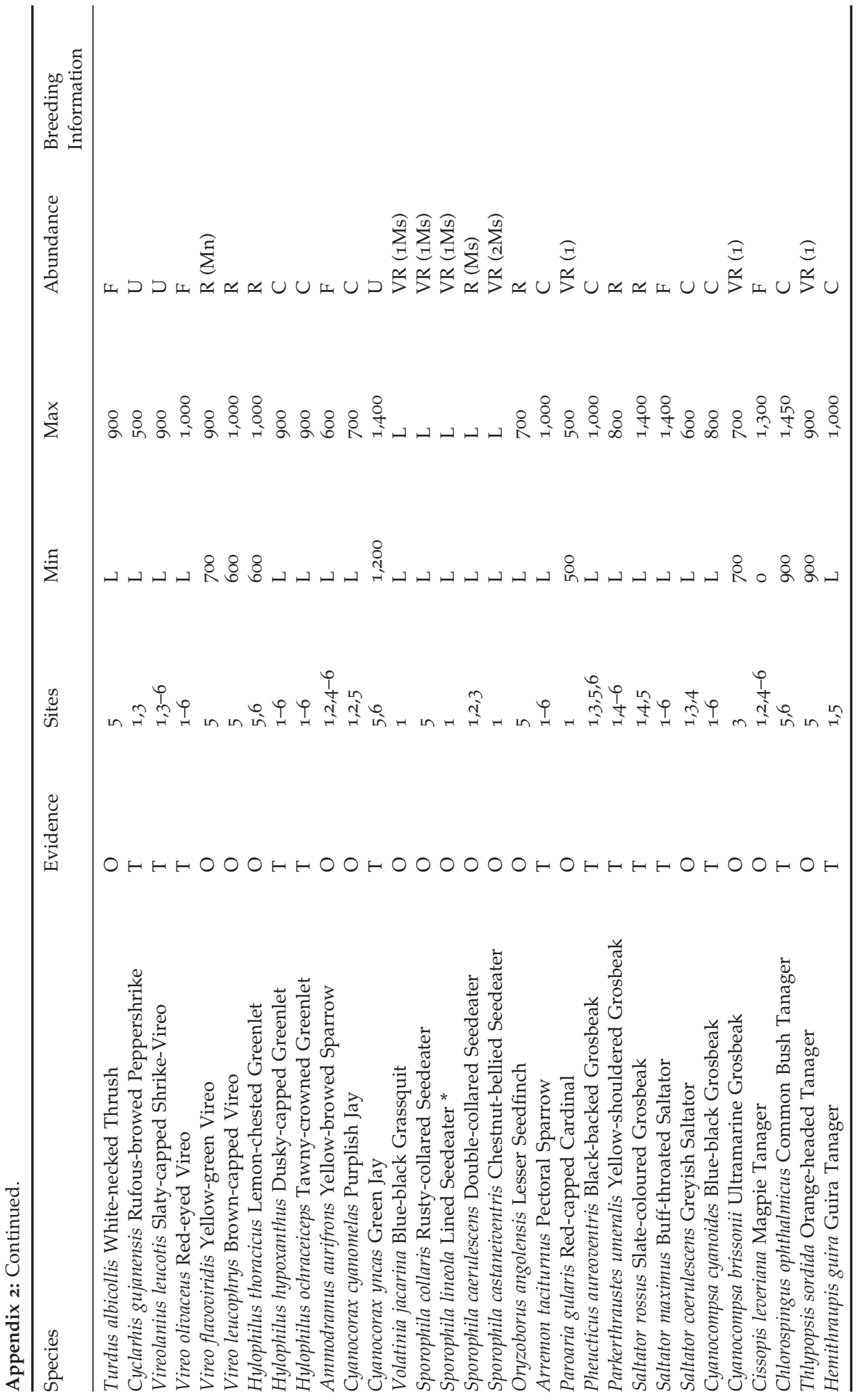


A.B. Hennessey et al.

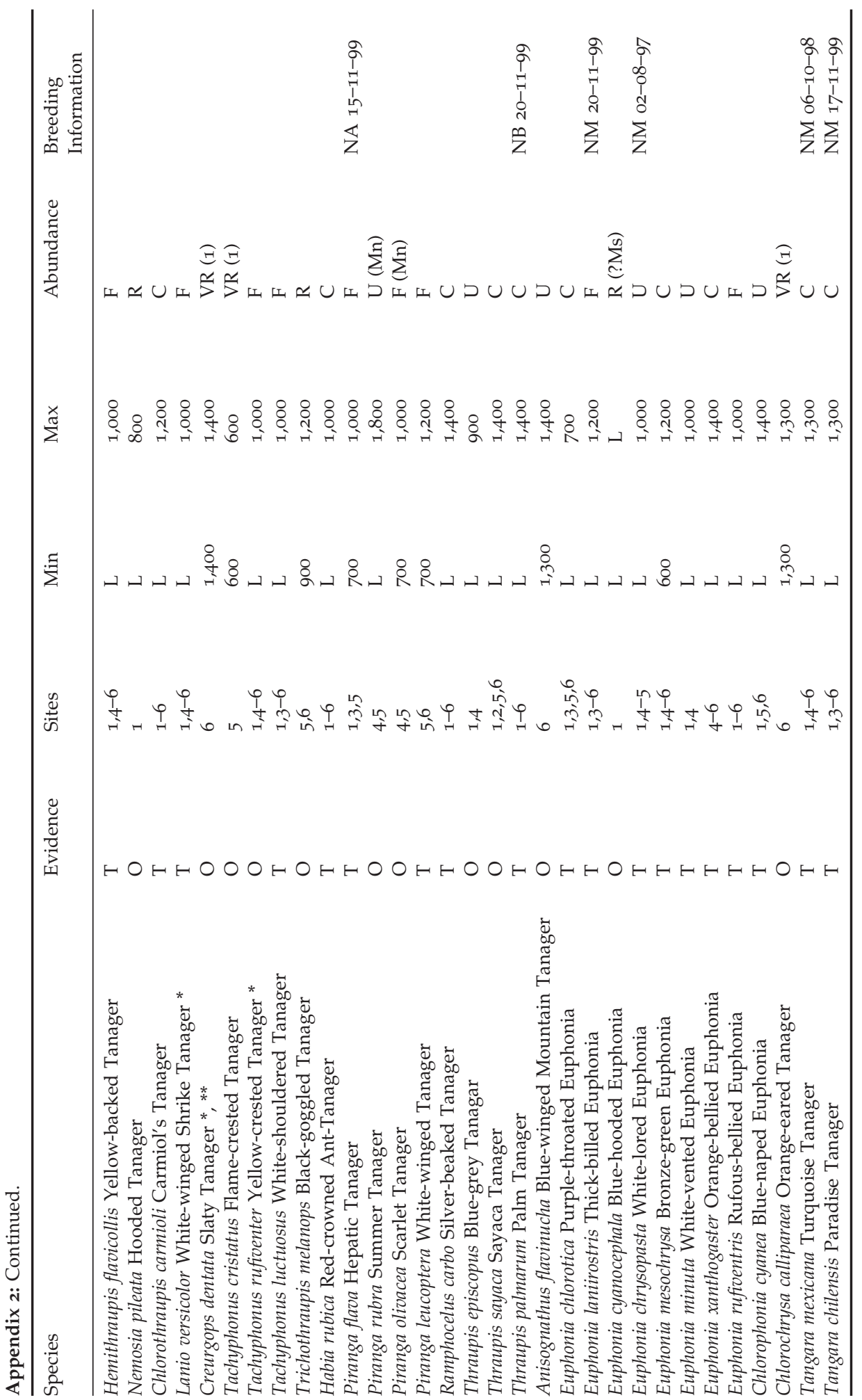




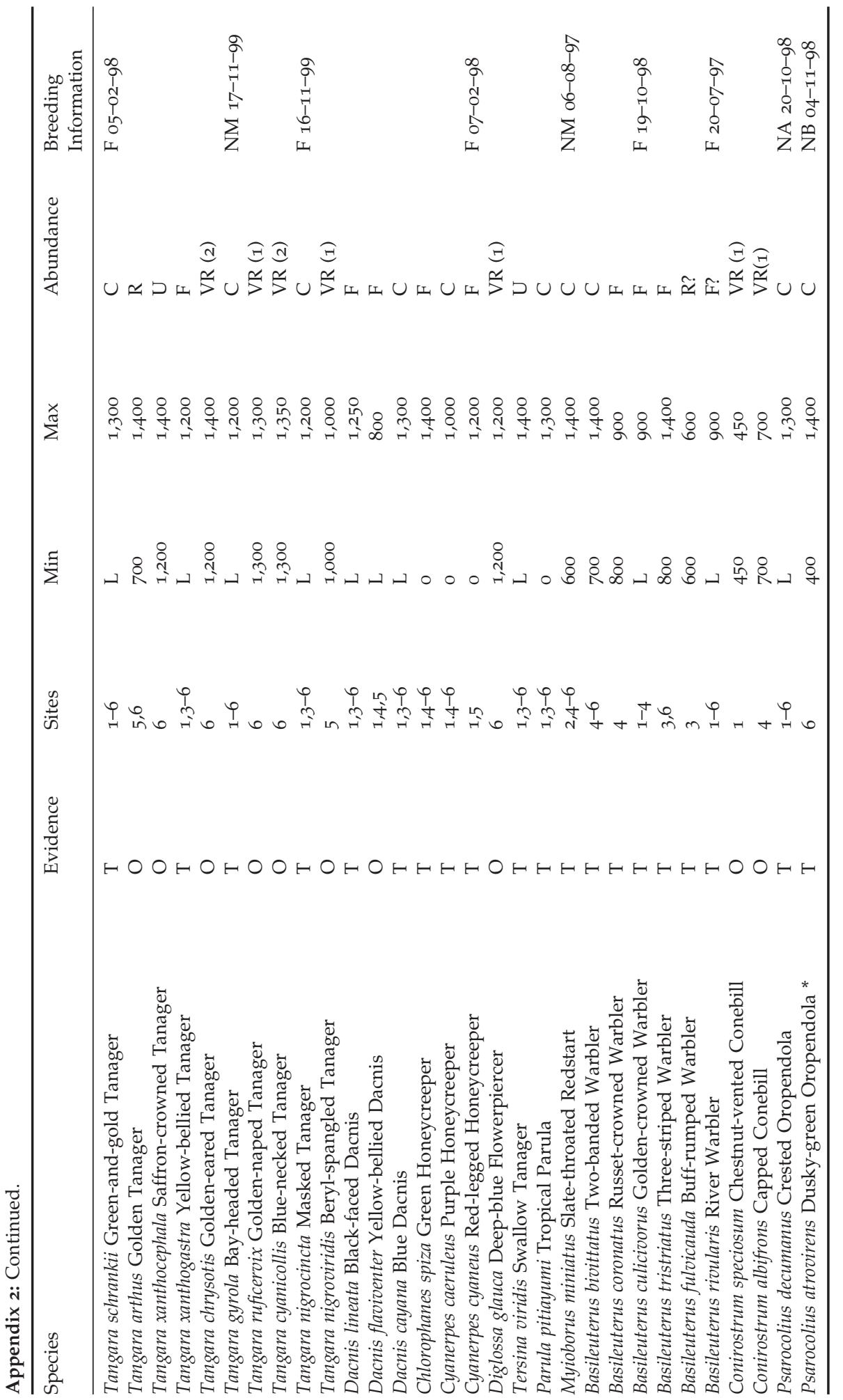




\section{References}

Arribas, M. A., Jammes, L. and Sagot, F. (1995) Lista de las aves de Bolivia. Santa Cruz: Armonía.

BirdLife International (2000) Threatened birds of the world. Barcelona and Cambridge, U.K.: Lynx Edicions and BirdLife International.

Haselmayer, J. and Quinn, J. S. (2000) A comparison of point counts and sound recording as bird survey methods in Amazonian southeast Peru. Condor 102: 887-893.

Hennessey, A. B., Herzog, S. K., Sagot, F. (2003) Lista Anotada de las Aves de Bolivia. Quinta edición. Santa Cruz de la Sierra, Bolivia: Asociación Armonía/BirdLife International.

Herzog, S. K., Soria A., R., Troncoso J., A. and Matthysen, E. (submitted MS) Composition and spatial structure of avian mixed-species flocks in a high-Andean Polylepis forest in Bolivia. Ecotropica.

Hilty, S. L. and Brown, W. L. (1986) A guide to the birds of Colombia. Princeton: Princeton University Press.

Jullien, M. and Thiollay, J. M. (1998) Multi-species territoriality and dynamic of neotropical forest understorey bird flocks. J. Anim. Ecol. 67: 227-252.

Kessler, M. (2001). Diversidad y endemismo de grupos selectos de plantas en la Serranía de Pilón Lajas, depto. Beni, Bolivia. Revista de la Sociedad Boliviana de Botánica 3: 124145 .

Mayer, S. (2000) Birds of Bolivia 2.o (CD-ROM). Westernieland: Bird Songs International.

McNair, D. B. and Escobar, J. (1993) Verified winter record of Scarlet Tanager in Charleston, SC, and a review of the winter status of Scarlet Tanager in the Southeast United States. Chat 57: 25-31.

Munn, C. A. (1985) Permanent canopy and understory flocks in Amazonia: species composition and population density. Orn. Monogr. 36: 683-712.

Parker, T. A., III. (1989) An avifaunal survey of the Chimanes Ecosystem Program Area of northern Bolivia. Unpublished report.

Parker, T. A., III. (1991) On the use of tape recorders in avifaunal surveys. Auk 108: 443444.

Parker, T. A., III, and Bailey, B. (1991) A Biological Assessment of the Alto Madidi Region and adjacent areas of Northwest Bolivia, May 18-June, 1990. Washington, D.C.: Conservation International (RAP Working Papers 1 ).

Parker, T. A., III, Remsen, J. V., Jr., and Heindel, J. A. (1980) Seven bird species new to Bolivia. Bull. Brit. Orn. Cl. 100: 160-162.

Parker, T. A., III., Castillo U., A., Gell-Mann, M. and Rocha O., O. (1991) Records of new and unusual birds from northern Bolivia. Bull. Brit. Orn. Cl. 111: 120-138.

Parker, T.A., III, Bates, J.M. and Cox, G. (1992) Rediscovery of the Bolivian Recurvebill with notes on other little-known species of the Bolivian Andes. Wilson Bull. 104: 173178.

Parker, T. A., Donahue, P. K. and Schulenberg, T. S. (1994) Birds of the Tambopata Reserve (Explorer's Inn Reserve). In R. B. Foster, T. A. Parker III, A. H. Gentry, L. H. Emmons, A. Chicchón, T. S. Schulenberg, L. Rodríguez, G. Lamas, H. Ortega, J. Icochea, W. Wust, M. Romo, J. A. Castillo, O. Phillips, C. Reynal, A. Kratter, P. K. Donahue and L. J. Barkley, eds. The Tambopata Reserved Zone of southeastern Peru: a biological assessment. Washington, D.C.: Conservation International (RAP Working Papers 6).

Parker, T. A., III., Stotz, D. F. and Fitzpatrick, J. W. (1996) Ecological and distributional databases. In D. F. Stotz, Fitzpatrick, J.W., Parker, T. A., III, and Moskovits, D.K. Neotropical birds: ecology and conservation. Chicago: University of Chicago Press.

Perry, A., Kessler, M. and Helme, N. (1997) Birds of the central Río Tuichi Valley, with emphasis on dry forest, Parque Nacional Madidi, dpto. La Paz, Bolivia. Orn. Monogr. 48: $557-576$. 
Remsen, J. V., Jr., and Traylor, M. A., Jr. (1989) An annotated list of the birds of Bolivia. Vermillion, SD: Buteo Books.

Sagot, F. (1998) Nuevas especies en el país en relación a la Lista de las Aves de Bolivia de Armonía de 1995. Pp. 25-31 in F. Sagot and J. Guerrero, eds. Aves y conservación en Bolivia No 1 (Actas IV Enc. Bol. Cons. Aves, 25-27 Oct. 97, Tarija). Santa Cruz: Armonía.

Smith, D. N. and Killeen, T. J. (1998) A comparison of the structure and composition of montane and lowland tropical forest in the Serranía Pilón Lajas, Beni, Bolivia. Pp. 681700 in F. Dallmeier and J. A. Comiskey, eds. Forest biodiversity in North, Central and South America and the Caribbean. Research and Monitoring. Paris and New York: UNESCO and Parthenon Publishing Group.

Seidel, R. (1995) Inventario de los árboles en tres parcelas de bosque primario en la Serranía de Marimonos, Alto Beni. Ecología en Bolivia 25: 1-35.

Stattersfield, A. J., Crosby, M. J., Long, A. J. and Wege, D. C. (1998) Endemic Bird Areas of the world. Cambridge, U.K.: BirdLife International.

Stotz, D. F., Fitzpatrick, J. W., Parker, T. A., III, and Moskovits, D.K. (1996) Neotropical birds: ecology and conservation. Chicago: University of Chicago Press.

Thomas B.T. (1999) Family: Steatornis. Pp 244-251 in J. Del Hoyo, A. Elliot and J. Sargatal, eds. The handbook of the birds of the world, V. Barcelona: Lynx Editions

\section{A. BENNETT HENNESSEY}

Armonía/ BirdLife Int., Casilla 3566, Santa Cruz, Bolivia. E-mail: tangara@unete.com

\section{SEBASTIAN K. HERZOG}

Institut für Vogelforschung "Vogelwarte Helgoland", An der Vogelwarte 21, 26386 Wilhelmshaven, Germany.

MICHAEL KESSLER

Albrecht-von-Haller-Institut für Pflanzenwissenschaften, Abteilung Systematische Botanik, Untere Karspüle 2, 37073 Göttingen, Germany.

DANIEL ROBISON

Rurrenabaque, La Paz, Bolivia. 
